\title{
Stable water isotopes of precipitation and firn cores from the northern Antarctic Peninsula region as a proxy for climate reconstruction
}

\author{
F. Fernandoy ${ }^{1}$, H. Meyer ${ }^{1}$, and M. Tonelli ${ }^{2}$ \\ ${ }^{1}$ Foundation Alfred Wegener Institute for Polar and Marine Research in the Helmholtz Association, Research Unit Potsdam, \\ Potsdam, Germany \\ ${ }^{2}$ Oceanographic Institute, University of São Paulo, Brazil
}

Correspondence to: F. Fernandoy (ffernandoy@gmail.com)

Received: 18 December 2010 - Published in The Cryosphere Discuss.: 17 March 2011

Revised: 30 January 2012 - Accepted: 7 February 2012 - Published: 22 March 2012

\begin{abstract}
In order to investigate the climate variability in the northern Antarctic Peninsula region, this paper focuses on the relationship between stable isotope content of precipitation and firn, and main meteorological variables (air temperature, relative humidity, sea surface temperature, and sea ice extent). Between 2008 and 2010, we collected precipitation samples and retrieved firn cores from several key sites in this region. We conclude that the deuterium excess oscillation represents a robust indicator of the meteorological variability on a seasonal to sub-seasonal scale. Low absolute deuterium excess values and the synchronous variation of both deuterium excess and air temperature imply that the evaporation of moisture occurs in the adjacent Southern Ocean. The $\delta^{18} \mathrm{O}$-air temperature relationship is complicated and significant only at a (multi)seasonal scale. Backward trajectory calculations show that air-parcels arriving at the region during precipitation events predominantly originate at the South Pacific Ocean and Bellingshausen Sea. These investigations will be used as a calibration for ongoing and future research in the area, suggesting that appropriate locations for future ice core research are located above $600 \mathrm{~m}$ a.s.l. We selected the Plateau Laclavere, Antarctic Peninsula as the most promising site for a deeper drilling campaign.
\end{abstract}

\section{Introduction}

It is well known that Antarctica plays a key role in the earth's climate regulation. The influence of the Antarctic Circumpolar Current on the ocean and atmosphere in the Southern Hemisphere demonstrates the strong interconnection of the climate dynamics (White and Peterson, 1996). Lately, Antarctica has been in the focus of scientific atten- tion, due to the elevated rate of atmospheric warming during the second half of the 20th century. The warming rate of $0.082^{\circ} \mathrm{C} \mathrm{decade}^{-1}$ as a mean value for whole Antarctica (Chapman and Walsh, 2007) is in fact close to the rate for the Southern Hemisphere warming (IPCC, 2007). However, the strong atmospheric warming detected over West Antarctica $\left(0.14^{\circ} \mathrm{Cdecade}^{-1}\right)$, especially over the western Antarctic Peninsula (WAP) $\left(0.4^{\circ} \mathrm{C}\right.$ decade $\left.^{-1}\right)$, has no counterpart in any other region of the world (Vaughan et al., 2003; Turner et al., 2005, 2009; Steig et al., 2009). The strongest trends were detected at coastal ground stations (e.g. Vernadsky Station (formerly Faraday): $0.56^{\circ} \mathrm{C}$ decade $^{-1}, 1951-2000$ ), and especially during winter seasons in the 1990s. Since then the temperature trend seems to be at least stabilized or decreased (Turner et al., 2005; Chapman and Walsh, 2007).

Until now the consequences of the present elevated temperature conditions are not fully understood. The South Pacific and Atlantic ocean's surface $(0-300 \mathrm{~m}$ depth) have raised in temperature by $0.13^{\circ} \mathrm{C}$ and $0.23^{\circ} \mathrm{C}$, respectively, for the period 1955-2003 in response to the elevated air temperatures (Levitus et al., 2005). Moreover, the sea surface temperature increase at the WAP reached more than $1^{\circ} \mathrm{C}$ for the period 1955-1998 during summer season (Meredith and King, 2005), with coincident retreat of the sea ice extent since 1958 (Abram et al., 2010). Warmer oceanic water triggers the melting of the base of ice shelves (Shepherd et al., 2004), leading to events like the disintegration of the Wordie ice shelf (Rignot et al., 2005). Thus, these events facilitate an accelerated discharge flow of inland glaciers to the ocean (De Angelis and Skvarca, 2003). The retreat of the ice shelves and sea ice act as a feedback mechanism for atmospheric warming and a clear anti-correlation of the sea ice extent and surface air temperature at WAP exists (Weatherly

Published by Copernicus Publications on behalf of the European Geosciences Union. 
et al., 1991; Turner et al., 2005; Bracegirdle et al., 2008). Up to $87 \%$ of 244 marine glacier fronts from the whole Antarctic Peninsula are presently retreating (Cook et al., 2005) and the height line of permanent dry snow has clearly ascended over the last decades (Rau and Braun, 2002; Tedesco et al., 2007). The warming of both the atmosphere and the ocean has been producing an increase of humidity, leading to raised snow accumulation rates in the southern WAP as shown by Thomas et al. (2008). However, the mass balance of the Antarctic Peninsula is negative with a loss of $\sim 38.1 \mathrm{Gta}^{-1}$, mostly concentrated in the central and north regions $\left(\sim-28.6 \mathrm{Gta}^{-1}\right)$ according to Chen et al. (2009). Nonetheless, Hall (2009) shows that the ice shelf grounding line of the Antarctic Peninsula has constantly retreated since the Last Glacial Maximum and reached its approximate present position during the early Holocene time, with some glacier advances at around $7 \mathrm{ka}, 5 \mathrm{ka}, 2 \mathrm{ka}$ and $0.7 \mathrm{ka}$ in the Holocene. According to Hall (2009) the present overall glacier retreat in the area of the Antarctic Peninsula is not unique in recent periods, but is now reaching warm conditions similar to those of the mid-Holocene within a short period of time (decades). Moreover, the ice shelf disintegration has not been detected even during the warm Holocene phases. The rapid warming of the WAP most likely originated from the intensification of the westerly circumpolar trough and increasing transport of heat from the ocean at lower latitudes, which has been related to the positive shift of the Southern Annular Mode (SAM) index (Marshall, 2003) since the 1960s (Thompson and Solomon, 2002; Gillett et al., 2006; Marshall et al., 2006). The intensification of SAM has recently been related to anthropogenic causes like increased concentration of greenhouse-gases in the atmosphere and stratospheric ozone depletion (Gillett et al., 2008). Little is known about when these processes started and their evolution through the industrial period. Additionally, the existing scarce meteorological data ( $\sim 50$ a) is often interrupted and clearly geographically-biased, because most of the stations are located at coastal regions. For these reasons, a better and deeper understanding of the climate variability of the last decades to centuries is still urgently needed for the region.

The stable isotope composition of Antarctic ice offers a unique proxy to extend the existing meteorological records well beyond the pre-instrumental times. The interpretation of this proxy is not straight forward and requires a detailed study of the different parameters affecting the isotope composition of precipitation stored in the glaciers. It has been demonstrated that precipitation reflects not only air temperature variations, but also conditions at the ocean surface, atmospheric teleconnections and circulation shifts, as well as other local effects (Ichiyanagi et al., 2002; Uemura et al., 2008; Thomas and Bracegirdle, 2009). Stable isotope (oxygen and hydrogen) content of water molecules in precipitation are considered as an excellent proxy to trace seasonal changes in air temperatures, especially in Polar Regions (Dansgaard, 1964; van Ommen and Morgan, 1997). Thermo- dynamic differences between the water molecules containing different stable isotopes of oxygen and hydrogen lead to the fractionation of water molecules $\left({ }^{18} \mathrm{O} /{ }^{16} \mathrm{O}\right.$ and ${ }^{2} \mathrm{H} / \mathrm{H}$ ratios) during water phase changes (such as evaporation). Moreover a continuous depletion of the heavy isotopes occurs relative to the temperature variation and trajectory of air masses during condensation (Dansgaard, 1964). Distillation of the heavy isotopes from an air mass will follow approximately a Rayleigh-type process (Dansgaard, 1964; Gat, 1996). Incloud condensation of moisture occurs in an approximately closed system and therefore the isotopic composition at the moment of precipitation will depend mainly on the local air temperature (Rozanski et al., 1993; Gat, 1996; Clark and Fritz, 1997). This makes the isotope composition of precipitation suitable to identify air temperature fluctuations (e.g. summer and winter oscillations) and changes in the air masses pathways and moisture sources. The secondary isotopic parameter known as deuterium excess $\left(d_{\text {excess }}\right)$, was defined by Dansgaard (1964) in the following relationship: $d=\delta D-8 \delta^{18} \mathrm{O}$. This parameter refers to the fractionation rate difference (or excess) of $\mathrm{HD}^{16} \mathrm{O}$ and $\mathrm{H}_{2}{ }^{18} \mathrm{O}$ during the evaporation of water vapor from the ocean (kinetic evaporation process). Since the posterior in-cloud condensation is considered to occur in equilibrium conditions (Dansgaard, 1964; Gat, 1996), the $d_{\text {excess }}$ generally does not undergo further modifications during the rain-out process. Therefore, $d_{\text {excess }}$ will depend mainly on the conditions at the evaporation moment, i.e. relative humidity $(h)$, sea surface temperature (SST) and wind speed at the moisture source. Because of these characteristics, $d_{\text {excess }}$ is useful to identify the moisture source conditions and to reconstruct variations of these conditions in time, a tool broadly accepted and well-suited for glacio-geochemical investigations (e.g. Stenni et al., 2010). Uemura et al. (2008) made direct measurements of water vapor above the sea level at southern high latitudes, as one of the first empirical validations of the $d_{\text {excess }}$ variability in response to sea surface conditions. They found that $d_{\text {excess }}$ negatively correlates with $h$ and positively correlates with SST, however, a strong and random variability is observed close to the Antarctic coast region.

In this paper we aim to construct a comprehensive isotope geochemical and hydrological data set to characterize the present climate and hydrological situation at the northern Antarctic Peninsula, a basis needed for on-going and future research in this region. This work is also aimed to contribute to the objectives of the newly created initiative of the Tropical to Polar Connections Institute (www.polartropical.org).

\section{Study area}

Our study focuses mainly on the northern Antarctic Peninsula and the South Shetland Islands. Two key regions were selected for our field work due to their glaciological potential, relatively easy access, adequate logistical facilities and 


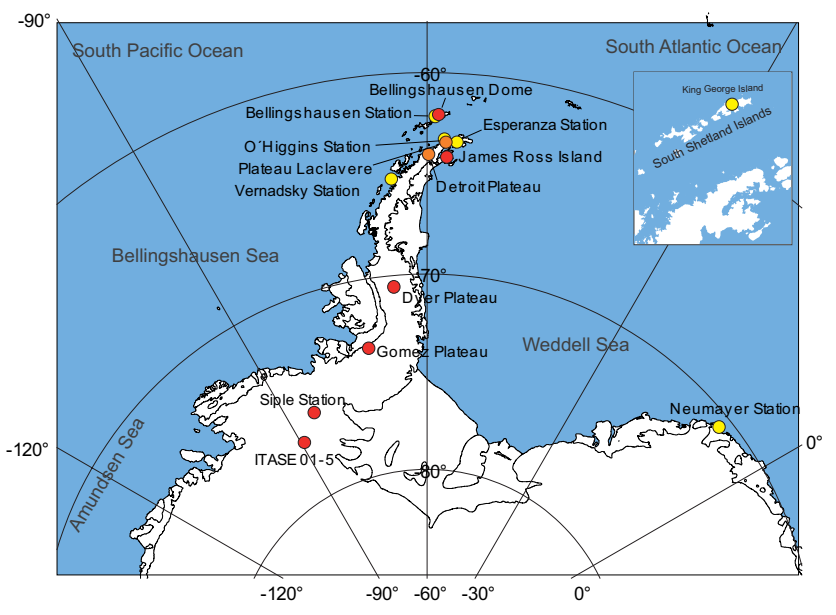

Fig. 1. Map showing all locations mentioned in this paper, as stations in Antarctica (yellow dots), ice/firn core retrieve locations (red points), and ongoing and future research areas (orange dots).

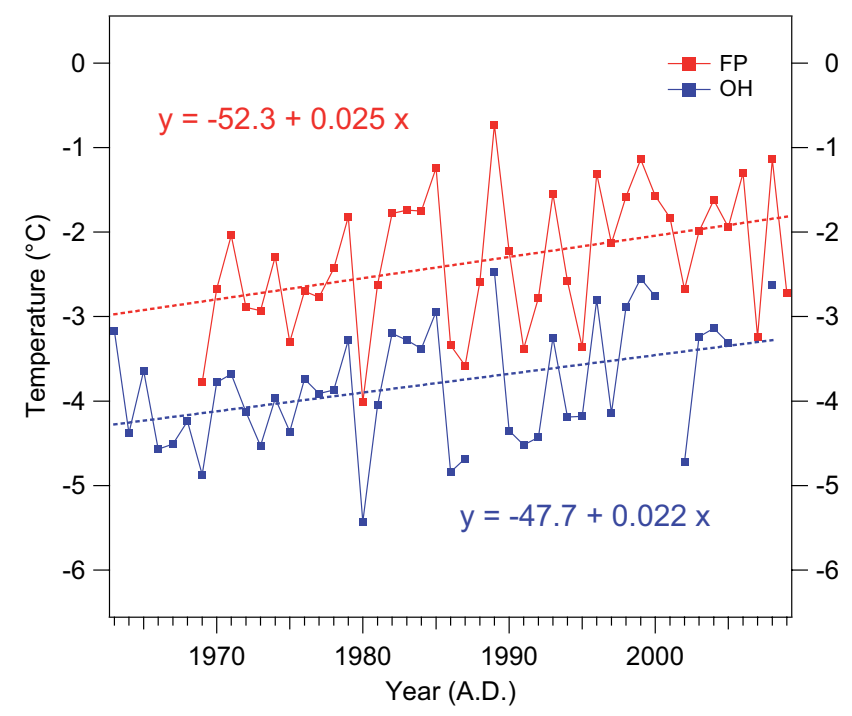

Fig. 2. Mean annual air temperature (MAAT) of the last 4 to 5 decades from Bellingshausen station (FP, red line), King George Island, and O'Higgins station (OH, blue line), Antarctic Peninsula. For both stations linear regression (dotted lines) are presented, as well as the annual air temperature trend (equations).

previous work. These two areas are the ice cap covering King George Island (KGI), South Shetland Islands, and the region south-east of the Chilean Antarctic Station "Bernardo O'Higgins" (later referred to as O'Higgins - $\mathrm{OH}$ ) at the Antarctic Peninsula (API) (Fig. 1).

$\mathrm{KGI}$ is a $1250 \mathrm{~km}^{2}$ island covered by an ice cap with an extension of more than $1158 \mathrm{~km}^{2}$ (>90\% of KGI) (Simões et al., 1999). The climate regime of the island is characterized by maritime conditions. The surface mean annual air temperature (MAAT) recorded at the Russian Station Bellingshausen is $-2.3{ }^{\circ} \mathrm{C}$ for the period $1968-2009$. A clear posi-

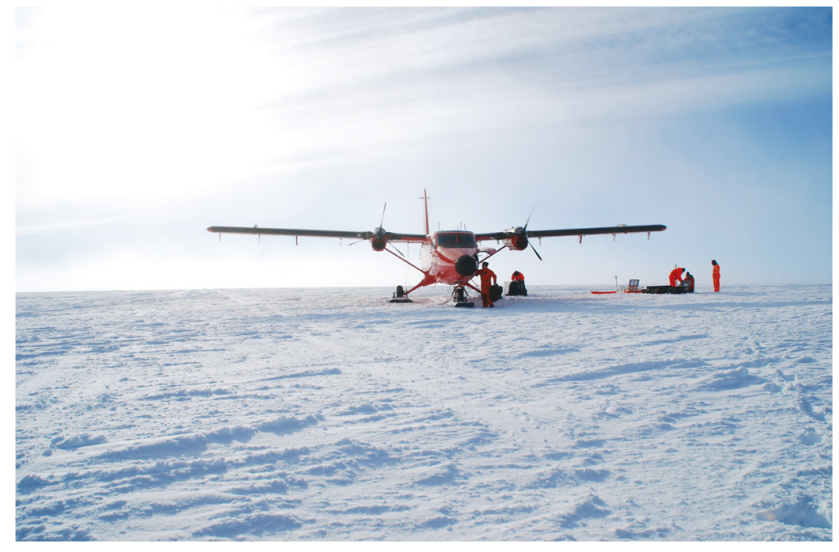

Fig. 3. Picture of the Plateau Laclavere $\left(63^{\circ} 27^{\prime} 10^{\prime \prime} \mathrm{S}, 57^{\circ} 45^{\prime} 32^{\prime \prime} \mathrm{W}\right.$, $1030 \mathrm{~m}$ a.s.1.) reached the first time on the 31 January 2010 with a Twin-Otter aircraft of the Chilean Air Force. From this location a firn core of $11 \mathrm{~m}$ depth was extracted $(\mathrm{OH}-6)$.

tive temperature trend of $0.025^{\circ} \mathrm{Ca}^{-1}$ is observed since the beginning of the meteorological record (Fig. 2). According to Blindow et al. (2010) and Rückamp et al. (2010), the ice cap of KGI displays a polythermal regime, with a lower temperate part and a cold part above $400 \mathrm{~m}$ a.s.l. However, the exact line of transition between temperate and cold regime is still a matter of discussion. The altitude of the ice cap reaches $700 \mathrm{~m}$ a.s.l. in the central region of KGI (Blindow et al., 2010). Rückamp et al. (2010) and Wen et al. (1998) estimate that the MAAT at the highest point of the ice cap should be around -6 to $-6.6^{\circ} \mathrm{C}$. This implies that the KGI ice cap is very sensitive to climate variability. The firn/ice transition was identified at $35 \mathrm{~m}$ depth by radio echo sounding profiles (Blindow et al., 2010) and by density profiles of ice cores retrieved at the main glacier dome (700 $\mathrm{m}$ a.s.1.) in this island (Simões et al., 2004). Both studies detected a water table above the firn/ice transition. As a consequence of the climatic conditions of the region, strong melting, melt water percolation, and refreezing processes are evident, thus making the drilling process and interpretation of the isotope signal in the temperate part of the ice cap complicated.

The second study region at the API had been much less explored and the scientific background is scarce. The coastal region displays similar meteorological conditions as for KGI, however, the MAAT at sea level is slightly lower $\left(-3.8^{\circ} \mathrm{C}\right)$ for the period 1963-2008 at the O'Higgins Station, which is located $140 \mathrm{~km}$ to the south of KGI (Fig. 1). The trend of the air temperature registered at this station is similar to that from KGI, with an increase of $0.022^{\circ} \mathrm{Ca}^{-1}$ (Fig. 2). The nearby Laclavere Plateau (1030 m a.s.1.), around $19 \mathrm{~km}$ to the southeast of $\mathrm{OH}$ (Fig. 1), was reached and explored for the first time during the austral summer 2010. The plateau has a flat surface of approximately $6 \mathrm{~km}$ long and $3 \mathrm{~km}$ wide (Fig. 3) and divides the warmer and moist west side from the colder and drier east side of API. Therefore, this plateau represents 


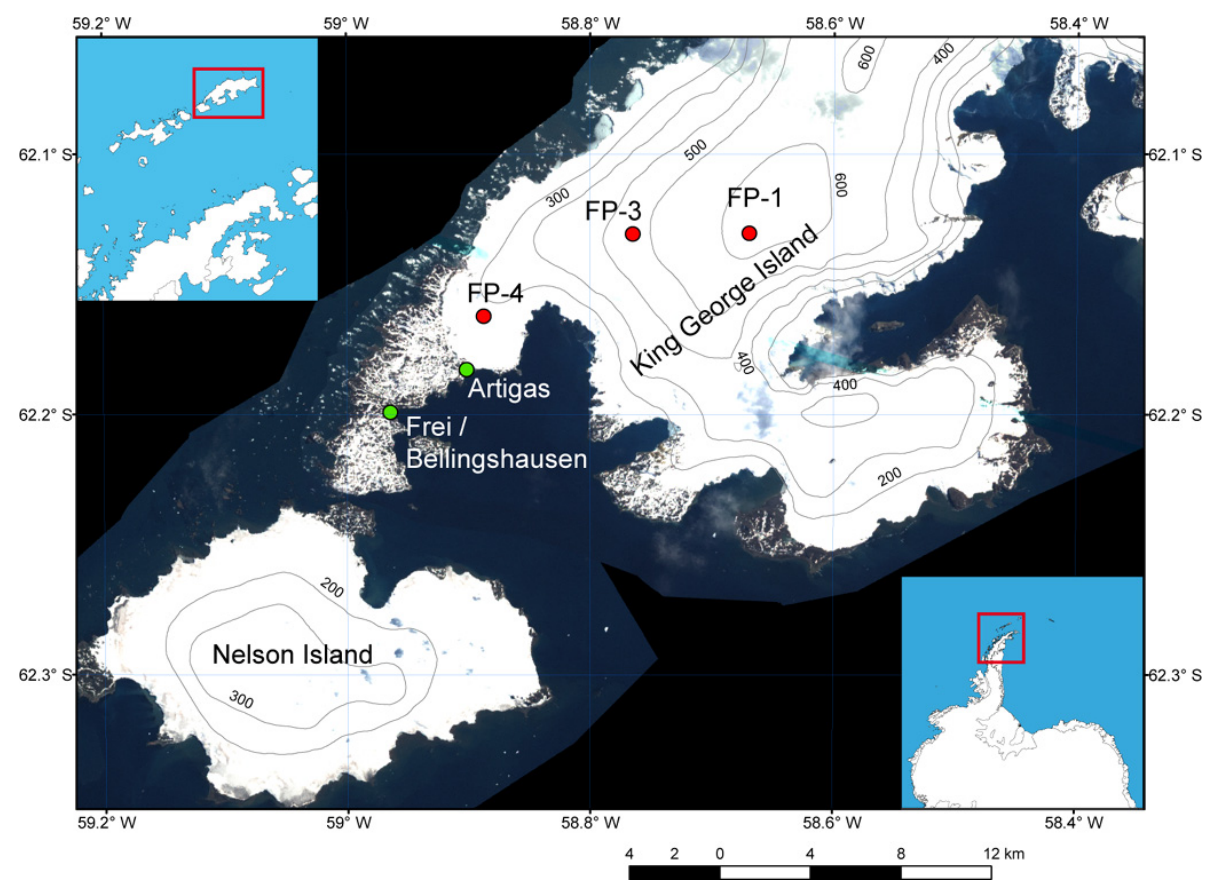

Fig. 4. Overview of the study area on King George Island (KGI), South Shetland Islands. Precipitation samples and meteorological data were collected at the Chilean station Frei and the neighbouring Russian station Bellingshausen; expeditions to the KGI glacier were organized from the Uruguayan station Artigas (green dots). Three firn cores (red dots) were retrieved from this area between the local Bellingshausen dome (FP-4) and the main dome of KGI (FP-1). The Landsat 7 satellite image is available at the LIMA website (http://lima.usgs.gov/). Contour lines shown are from the Antarctic Digital Database (ADD) (www.add.scar.org:8080/add).

a key location to investigate the recent climate variation of the region. Using the same temperature gradients invoked by Rückamp et al. (2010) and Wen et al. (1998), the MAAT at Laclavere should be around $-10^{\circ} \mathrm{C}$, and since the air temperature oscillation recorded at $\mathrm{OH}$ is in the range of $\pm 3.6^{\circ} \mathrm{C}$, monthly mean air temperature should stay the whole year below the freezing point, making this area ideal for glaciological investigations.

In addition to the ice-coring work a network for collecting precipitation samples was established in cooperation with the Chilean Meteorological Service (DMC) and the Antarctic Department of the Chilean Army (DAE). Two stations collect precipitation samples and provide the meteorological record on a daily schedule since 2008 until present. These are located at the Antarctic Chilean Stations Eduardo Frei (FP) and Bernardo O'Higgins $(\mathrm{OH})$, situated on Fildes Peninsula, KGI, and the API, respectively (Fig. 1).

\section{Methods}

During three consecutive summer campaigns (2008-2010), several firn cores (more than $80 \mathrm{~m}$ in total) were retrieved from KGI and the northern part of API. At both localities, an altitudinal profile was completed from sea level up to $1030 \mathrm{~m}$ a.s.l. A total of 7 firn cores are included in this paper: FP-1, FP-3 and FP-4 from KGI (Fig. 4), and OH-1, OH-
4, OH-5 and OH-6 from API (Fig. 5); coordinates and further details of the firn cores are given in Table 1. At both stations of the precipitation collection network more than 300 samples were gathered (Table 2). The firn cores were retrieved using a mechanical $9 \mathrm{~cm}$ diameter drilling device (Rufli auger), stored frozen at O'Higgins and at the Chilean scientific station Escudero (King George Island) and later transported to the ice core processing facilities of the Alfred Wegener Institute in Bremerhaven, Germany. There, the cores were sampled with a $5 \mathrm{~cm}$ resolution for stable isotope analyses. A visual logging and description of the cores was carried out to identify melt layers. Thereafter, firn and recent precipitation samples were analyzed by Finnigan Delta$\mathrm{S}$ mass spectrometers, following the gas equilibration technique as described by Meyer et al. (2000), with a precision better than $0.1 \%$ or oxygen and $0.8 \%$ for deuterium isotopes. Stable isotope data are later compared to major meteorological and synoptic features of the region. For this purpose different data sets are incorporated to our analysis. Meteorological data at daily and monthly resolutions are available from the Global Summary of the Day (GSOD) data sets of the National Climatic Data Center (NCDC, available at: www.ncdc.noaa.gov), and the SCAR Reference Antarctic Data for Environmental Research (READER, available at: www.antarctica.ac.uk/met/READER/) (Turner et al., 2004), respectively. Sea ice fraction (SIF) and sea 


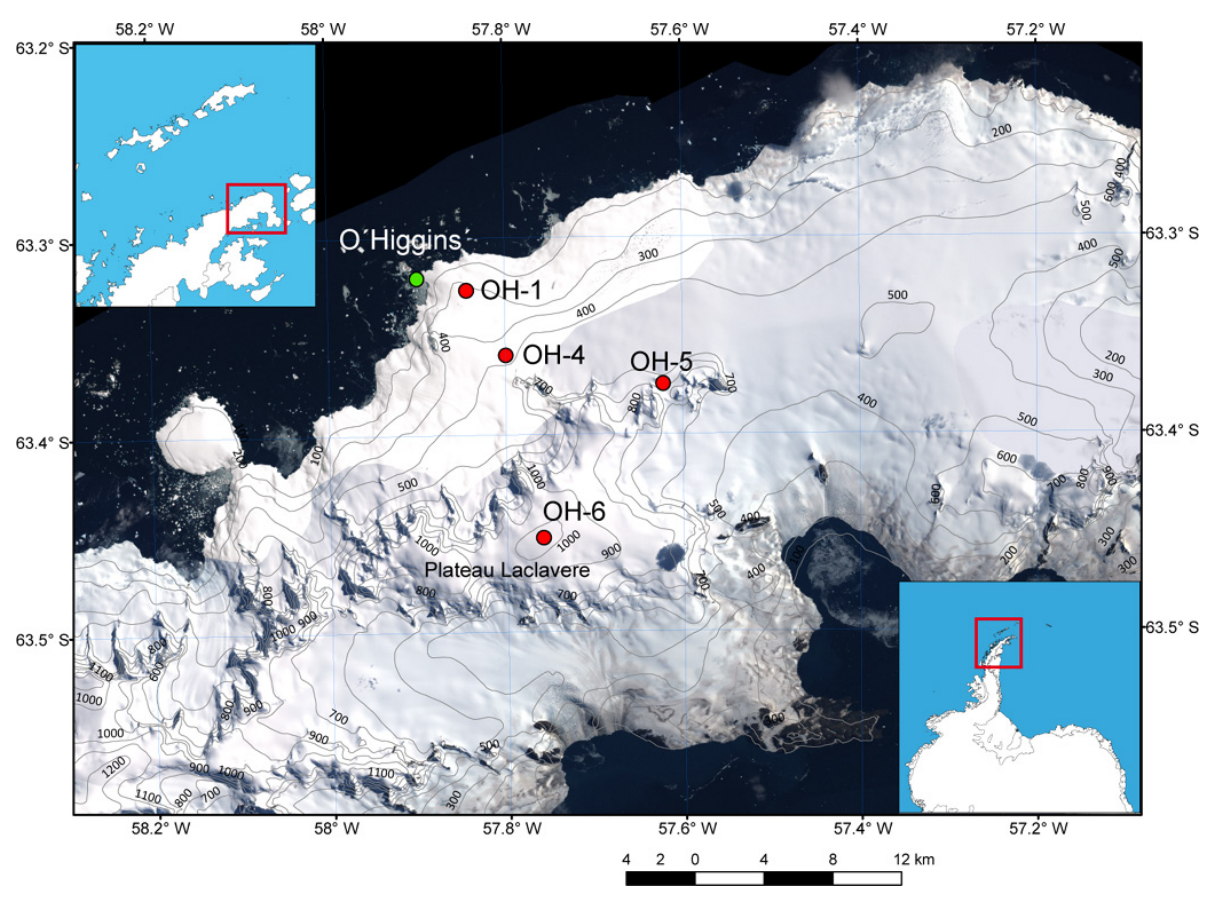

Fig. 5. Study area in the northern Antarctic Peninsula region. The Chilean station O'Higgins (green dot) is located at the west side of the Antarctica Peninsula on the Isabel Riquelme Islet facing the Bransfield strait. At this station precipitation samples and meteorological data were collected. Between the O'Higgins station and the Plateau Laclavere (1030 m a.s.1.) four firn cores (red dots) were retrieved during 2008 and 2010. The Landsat 7 satellite image is available at the LIMA website (http://lima.usgs.gov/). Contour lines shown are from the Antarctic Digital Database (ADD) (www.add.scar.org:8080/add).

surface temperature (SST) time series were extracted from the Hadley Centre Sea Ice and Sea Surface Temperature data set (HadISST, http://hadobs.metoffice.com/hadisst/). The HadISST provides SST and SIF on a global $1^{\circ}$ to $1^{\circ}$ grid in monthly means from 1973 to the present (Rayner et al., 2003). SIF fields results from a blend of in situ sea surface observations and a special sensor satellite estimates from the microwave/imager SSM/I. NCEP/NCAR reanalysis data (Kalnay et al., 1996) were used to estimate the relative humidity $(h)$ of the region. This reanalysis uses a state-of-theart analysis/forecast system to perform atmospheric data assimilation from 1948 to the present. Datasets are provided in a $2.5^{\circ}$ to $2.5^{\circ}$ latitude-longitude regular grid. HadISST and NCEP/NCAR fields were resampled to a regional scale in a Bellingshausen component (West Antarctic Peninsula), Weddell Sea component (East Antarctic Peninsula) and a whole region component (Bellingshausen and Weddell composite). The fields were resampled bordered by $85^{\circ} \mathrm{W}$ to $40^{\circ} \mathrm{W}$ longitude and $60^{\circ} \mathrm{S}$ to $90^{\circ} \mathrm{S}$ latitude limits. A field horizontal mean was computed to construct the time series used. Additionally, for each precipitation event registered at O'Higgins station, a 3-day air parcel backward trajectory was calculated to identify the moisture mass provenance. For this purpose, we used the free accessible Hybrid single-particle Lagrangian integrated trajectory (HYSPLIT) model (Draxler and Hess, 1998, available at http://ready.
arl.noaa.gov/HYSPLIT.php). This 3-D model was fed with the global data assimilation system (GDAS) archives from NOAA/NCEP (Kanamitsu, 1989). GDAS offers a global $1^{\circ}$ to $1^{\circ}$ latitude-longitude spatial coverage with a 6-h temporal resolution and is available from 2004 to the present (for more details visit http://ready.arl.noaa.gov/gdas1.php). Single trajectories were later grouped in 4 major clusters for each station, following a statistical treatment that calculates the spatial variance of the trajectories.

\section{Results and discussion}

\section{$4.1 \quad \delta^{18} O$ and $\delta D$}

In the next section, oxygen and hydrogen stable water isotopes of precipitation and firn core samples are presented, compared and discussed. All results are referred to the Vienna Standard Mean Ocean Water Standard (VSMOW) in $\%$, as $\delta^{18} \mathrm{O}$ and $\delta D$ for oxygen and hydrogen isotopes, respectively.

\subsubsection{Precipitation samples}

Table 2 shows the results and basic statistics for the precipitation samples collected at FP and $\mathrm{OH}$ stations. At both stations the collection period was 14 months (February 2008 to 
Table 1. Geographical location, mean isotope values and basic statistics of the high resolution $(5 \mathrm{~cm})$ stable isotope analyses of all firn cores retrieved from King George Island (FP) and the northern Antarctic Peninsula (OH).

\begin{tabular}{|c|c|c|c|c|c|c|c|}
\hline Core & FP-1 & FP-3 & FP-4 & $\mathrm{OH}-1$ & $\mathrm{OH}-4$ & OH-5 & OH-6 \\
\hline Site & KGI & KGI & KGI & API & API & API & API \\
\hline Coordinates & $\begin{array}{c}62.13^{\circ} \mathrm{S}, \\
58.67^{\circ} \mathrm{W}\end{array}$ & $\begin{array}{l}62.13^{\circ} \mathrm{S} \\
58.77^{\circ} \mathrm{W}\end{array}$ & $\begin{array}{c}62.16^{\circ} \mathrm{S} \\
58.89^{\circ} \mathrm{W}\end{array}$ & $\begin{array}{c}63.33^{\circ} \mathrm{S}, \\
57.84^{\circ} \mathrm{W}\end{array}$ & $\begin{array}{c}63.36^{\circ} \mathrm{S}, \\
57.80^{\circ} \mathrm{W}\end{array}$ & $\begin{array}{c}63.38^{\circ} \mathrm{S}, \\
57.62^{\circ} \mathrm{W}\end{array}$ & $\begin{array}{l}63.45^{\circ} \mathrm{S}, \\
57.76^{\circ} \mathrm{W}\end{array}$ \\
\hline Drilling date & 11 Jan 2009 & 6 Feb 2009 & 8 Feb 2009 & 23 Jan 2008 & 19 Jan 2009 & 31 Jan 2009 & 30 Jan 2010 \\
\hline Altitude (m a.s.1.) & 620 & 440 & 130 & 220 & 350 & 620 & 1030 \\
\hline Depth (m) & 15.56 & 15.28 & 1.42 & 14.96 & 15.75 & 10.6 & 11.02 \\
\hline \multicolumn{8}{|l|}{$\delta^{18} \mathrm{O}(\% \circ)$} \\
\hline Mean & -9.2 & -9.7 & -7.8 & -9.7 & -10.4 & -10.2 & -12.0 \\
\hline Sdev & 1.5 & 0.9 & 0.4 & 0.4 & 1.2 & 1.5 & 2.5 \\
\hline Min & -18.2 & -13.7 & -8.5 & -11.3 & -14.1 & -14.2 & -19.8 \\
\hline $\operatorname{Max}$ & -5.2 & -6.8 & -6.6 & -8.7 & -7.0 & -7.2 & -6.5 \\
\hline \multicolumn{8}{|l|}{$\delta D(\% o)$} \\
\hline Mean & -70.2 & -73.7 & -61.4 & -75.3 & -78.9 & -78.1 & -91.4 \\
\hline Sdev & 12.1 & 6.9 & 3.5 & 2.9 & 9.7 & 12.0 & 19.4 \\
\hline Min & -142.8 & -105.8 & -65.8 & -88.9 & -108.2 & -111.2 & -154.9 \\
\hline Max & -40.3 & -43.9 & -50.1 & -67.4 & -54.0 & -52.1 & -53.2 \\
\hline \multicolumn{8}{|l|}{$d_{\text {excess }}(\% o)$} \\
\hline Mean & 3.8 & 3.8 & 1.2 & 2.2 & 4.0 & 3.9 & 4.4 \\
\hline Sdev & 2.5 & 1.9 & 0.6 & 0.8 & 1.5 & 1.7 & 2.8 \\
\hline Min & -3.3 & -2.3 & 0.2 & 0.0 & 0.5 & -0.6 & -2.6 \\
\hline Max & 13.7 & 11.0 & 2.6 & 5.0 & 8.6 & 8.2 & 15.0 \\
\hline$n$ (samples) & 308 & 303 & 27 & 256 & 318 & 213 & 124 \\
\hline Samples a $a^{-1}$ (approx.) & 87 & 97 & - & 81 & 87 & 88 & 95 \\
\hline Accumulation $\left(\mathrm{kg} \mathrm{m}^{-2} \mathrm{a}^{-1}\right)$ & 2250 & - & - & - & - & - & 2350 \\
\hline
\end{tabular}

March 2009). Unfortunately an extended gap in time during the collection in winter occurs at FP, as a consequence of logistic difficulties. Therefore, we base our analysis mainly on the samples collected at $\mathrm{OH}$ and transfer the conclusions to KGI, since meteorological conditions like mean air temperature (here referred to as $T_{\text {air }}$ ) of both localities highly correlate on a daily to seasonal time scale $(r=0.89, p<0.01$; February 2008 to March 2010). From the $\mathrm{OH}$ meteorological record, the mean daily $T_{\text {air }}$ during the whole sampling period $\left(-2.1^{\circ} \mathrm{C}\right)$ is around $0.3^{\circ} \mathrm{C}$ lower than the mean daily air temperature calculated only for days with precipitation events $T_{\mathrm{p}}$. In parallel, a lower mean air pressure at sea level is observed during days with precipitation events compared to the whole period $\left(\mathrm{MSLP}_{\mathrm{p}}=983.2 \mathrm{mbar}\right.$ is $5 \mathrm{mbar}$ lower than MSLP $_{\text {air }}$ ) (Table 3). It should be noted that the year 2008 was around $0.8^{\circ} \mathrm{C}$ warmer than the average of the past 2 decades (1989-2009), but an anomaly in MSLP has not been detected. The collected precipitation samples show almost no seasonal difference in the distribution of the precipitation events during 2008-2009. 33, 35, 36 and 35 precipitation events were registered during summer (DJF), autumn (MAM), winter (JJA) and spring (SON), respectively.
On a monthly scale, a semi-annual behavior in the number of events is apparent with maxima at the end of summer and during spring, and an extreme peak in June 2008 (16 events). The semi-annual distribution at $\mathrm{OH}$ is coincident with long-term meteorological observations at FP (Carrasco and González, 2007). These characteristics reflect mainly the frontal-system origin of the precipitation events for this area and a constant year-round approach of fronts reaching this station. The isotope analysis of the precipitation samples show that mean $\delta^{18} \mathrm{O}$ value of $\mathrm{OH}(-9.2 \%)$ is more depleted than the mean value of $\mathrm{FP}(-7.9 \%$ o). It is likely that this marked difference is not completely caused by a latitudinal effect (temperature difference) between both stations, but rather explained by a biased sampling due to the lack of winter samples at FP. This bias is confirmed by calculation of the combined spring-summer (SON and DJF) average, obtained by subtracting the autumn-winter (MAM and JJA) means, which show similar $\delta^{18} \mathrm{O}$ values for both $\mathrm{OH}$ $(-8.9 \%)$ and for FP $(-8.1 \% \circ) 24$ stations, respectively. As mentioned before, usually a correlation between air (condensation) temperature and $\delta^{18} \mathrm{O}(\delta D)$ composition of precipitation exists, yet the observed relationship is not easy to 
Table 2. Mean $\delta^{18} \mathrm{O}$ and $\delta D$ values and basic statistics of precipitation samples collected between February 2008 and March 2009, and geographical coordinates of the corresponding collection stations: Frei (Fildes Peninsula, King George Island, South Shetland Islands) and O'Higgins (North Antarctic Peninsula).

\begin{tabular}{lrr}
\hline Station: & Frei (FP) & \multicolumn{2}{c}{$\mathrm{O}^{\prime}$ Higgins $(\mathrm{OH})$} \\
Coordinates: & $62.2^{\circ} \mathrm{S}, 58.96^{\circ} \mathrm{W}$ & $63.32^{\circ} \mathrm{S}, 57.9^{\circ} \mathrm{W}$ \\
m a.s.1.: & 45 & 13 \\
\hline$\delta^{18} \mathrm{O} \%$ r & & \\
\hline Mean & -7.9 & -9.2 \\
Sdev & 2.6 & 3.3 \\
Min & -15.7 & -19.4 \\
Max & -1.8 & -3.8 \\
\hline$\delta D(\% o)$ & & -70.5 \\
\hline Mean & -62.3 & 26.4 \\
Sdev & 20.8 & -150.6 \\
Min & -126.5 & -21.8 \\
Max & -10.7 & \\
\hline$d_{\text {excess }}(\%)$ & & 4.7 \\
\hline Mean & 0.6 & -6.6 \\
Sdev & 2.5 & 22.3 \\
Min & -5.0 & 139 \\
Max & 6.9 & \\
\hline$n$ (samples $)$ & 66 & \\
\hline
\end{tabular}

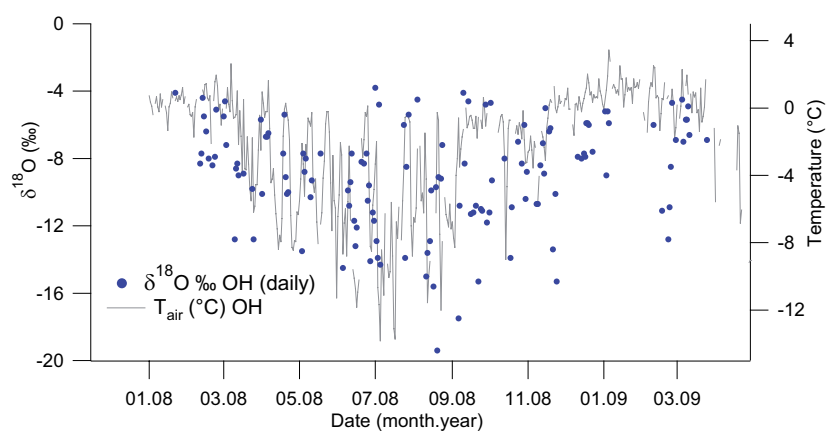

Fig. 6. Isotopic composition of precipitation samples (blue dots) collected at O'Higgins station in a daily schedule during February 2008 and March 2009. The mean daily temperatures (light grey line) for O'Higgins are displayed as well. A high variability of air temperature and isotope data is observed, especially during the winter season.

understand (Fig. 6). The isotope composition of precipitation at daily resolution correlates relative poorly with $T_{\mathrm{p}}$ $(r=0.35, p<0.01)$. This is mostly related to the meteorological instability and low temperature oscillation (standard deviation, $\sigma_{\text {air }}=3.5^{\circ} \mathrm{C}$ ), typical for the maritime influence and for the complexity of the isotope fractionation process at coastal regions (Carrasco et al., 2003; Noone, 2008; Sime et

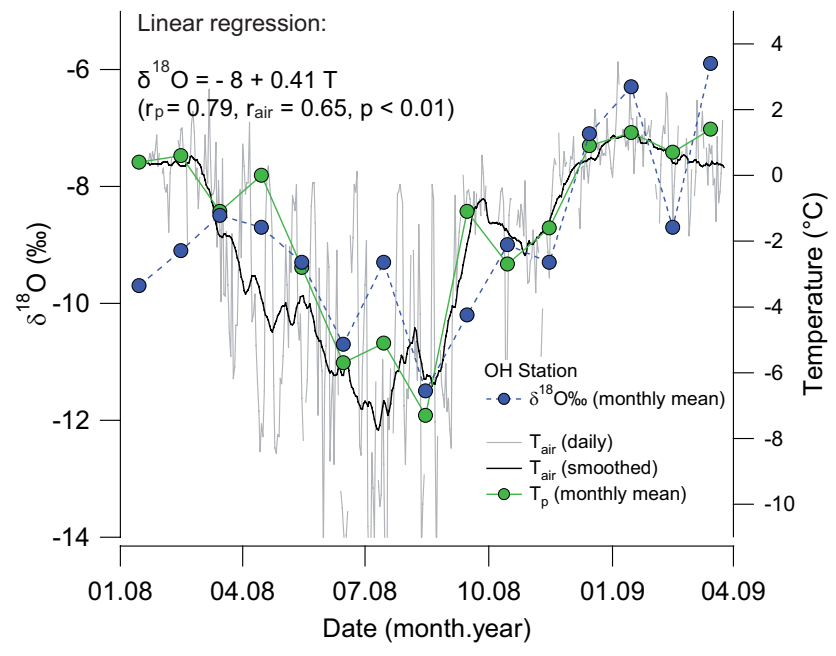

Fig. 7. Mean monthly $\delta^{18} \mathrm{O}$ values (blue dots) of precipitation samples collected at O'Higgins station. Also shown are data of mean monthly air temperature during precipitation days only $\left(T_{\mathrm{p}}\right.$, green dots), daily record ( $T_{\text {air }}$, light grey) and smoothed record $T_{\text {air }}$ (30 day smoothing, black line) at this station. A clear seasonal variability of $\delta^{18} \mathrm{O}$ is observed, linear regression of the $\delta^{18} \mathrm{O}$ and $T$ correlation is presented in the figure.

al., 2009). On the other hand, monthly averages calculated from daily events, significantly improve the $\delta^{18} \mathrm{O} / T$ correlation coefficient $(r=0.79, p<0.01)$ (Fig. 7). The improvement of the $\delta^{18} \mathrm{O} / T$ correlation is produced by the smoothing of (high) daily $T_{\text {air }}$ variability, and therefore the seasonal oscillation is enhanced. This confirms that $\delta^{18} \mathrm{O}$ composition of precipitation, at least on a seasonal scale, indeed captures the $T_{\text {air }}$ variations of the region, despite of the limited seasonal temperature fluctuations. The temperature difference between monthly $T_{\text {air }}$ and $T_{\mathrm{p}}$ (Table 3 ) at a monthly scale is around $T_{\mathrm{p}}=T_{\text {air }}+0.5^{\circ} \mathrm{C}$. For this reason a correction has to be applied for the $\delta^{18} \mathrm{O} / T_{\text {air }}$ relationship. From the monthly means a $\delta^{18} \mathrm{O} / T$ gradient of $0.41 \%{ }^{\circ} \mathrm{C}^{-1}$ has been calculated, being quite similar to that determined for the Ukrainian station Vernadsky (formerly Faraday) (Peel et al., 1988; Thomas and Bracegirdle, 2009). The Vernadsky Station has an extensive isotopic data base of more than 40 a, which started in 1964 and finished in 2005, while the meteorological record expands from 1947 to the present. From the $\delta D / \delta^{18} \mathrm{O}$ relation (Craig, 1961; Rozanski et al., 1993), known as meteoric water line (MWL), more detailed conclusions on the origin and evolution of the moisture masses can be drawn. Slope and $\delta D$ intercept of the Local MWL (LMWL) result from the evaporation setting at the moisture source and the local condensation conditions. The slope of the LMWL at $\mathrm{OH}(m=7.89)$ is very close to the Global MWL (GMWL; $m=8.13$ ) (Rozanski et al., 1993), indicating that condensation process occurs in equilibrium conditions. Additionally, no seasonal variations of the condensation conditions (seasonal effect) are interpreted from our data. The 
Table 3. Basic statistics of air temperature and air pressure at sea level for Bellingshausen Station at Fildes Peninsula (FP) and O'Higgins Station $(\mathrm{OH})$, separately calculated for days with precipitation $\left(T_{\mathrm{p}}\right.$ and $\left.\mathrm{SLP}_{\mathrm{p}}\right)$ and for the whole collection period $\left(T_{\text {air }}, \mathrm{SLP}_{\text {air }}\right)$.

\begin{tabular}{|c|c|c|c|c|c|c|c|c|c|}
\hline \multicolumn{5}{|c|}{ Bellingshausen - daily } & \multicolumn{5}{|c|}{ Bellingshausen - monthly means } \\
\hline & $\begin{array}{l}T_{\text {air }} \\
\left({ }^{\circ} \mathrm{C}\right)\end{array}$ & $\begin{array}{r}T_{\mathrm{p}} \\
\left({ }^{\circ} \mathrm{C}\right)\end{array}$ & $\begin{array}{l}\mathrm{SLP}_{\text {air }} \\
\text { (mbar) }\end{array}$ & $\begin{array}{r}\mathrm{SLP}_{\mathrm{p}} \\
\text { (mbar) }\end{array}$ & & $\begin{array}{r}T_{\text {air }} \\
\left({ }^{\circ} \mathrm{C}\right)\end{array}$ & $\begin{array}{r}T_{\mathrm{p}} \\
\left({ }^{\circ} \mathrm{C}\right)\end{array}$ & $\begin{array}{l}\mathrm{SLP}_{\text {air }} \\
\text { (mbar) }\end{array}$ & $\begin{array}{r}\mathrm{SLP}_{\mathrm{p}} \\
(\mathrm{mbar})\end{array}$ \\
\hline Mean & -0.7 & 0.5 & 990.1 & 985.7 & Mean & -0.4 & -0.1 & 988.4 & 984.9 \\
\hline Sdev & 3.1 & 2.7 & 12 & 11.0 & Sdev & 2.3 & 2.9 & 4.8 & 6.8 \\
\hline Min & -12.8 & -9.6 & 951.7 & 956.1 & Min & -5.1 & -8.0 & 982.2 & 975.6 \\
\hline Max & 3.8 & 3.7 & 1025.3 & 1015.2 & Max & 2.1 & 2.2 & 1001.3 & 1001.1 \\
\hline$n$ (events) & 406 & 62 & 402 & 61 & $n$ (events) & 12 & 12 & 12 & 12 \\
\hline \multicolumn{5}{|c|}{ O'Higgins - daily } & \multicolumn{5}{|c|}{ O'Higgins - monthly means } \\
\hline & $\begin{array}{l}T_{\text {air }} \\
\left({ }^{\circ} \mathrm{C}\right)\end{array}$ & $\begin{array}{r}T_{\mathrm{p}} \\
\left({ }^{\circ} \mathrm{C}\right)\end{array}$ & $\begin{array}{l}\text { SLP }_{\text {air }} \\
\text { (mbar) }\end{array}$ & $\begin{array}{r}\mathrm{SLP}_{\mathrm{p}} \\
\text { (mbar) }\end{array}$ & & $\begin{array}{r}T_{\text {air }} \\
\left({ }^{\circ} \mathrm{C}\right)\end{array}$ & $\begin{array}{r}T_{\mathrm{p}} \\
\left({ }^{\circ} \mathrm{C}\right)\end{array}$ & $\begin{array}{l}\mathrm{SLP}_{\text {air }} \\
\text { (mbar) }\end{array}$ & $\begin{array}{r}\mathrm{SLP}_{\mathrm{p}} \\
(\mathrm{mbar})\end{array}$ \\
\hline Mean & -2.3 & -2.0 & 988.7 & 983.2 & Mean & -2.1 & -1.6 & 989.0 & 983.3 \\
\hline Sdev & 3.6 & 3.7 & 12.0 & 11.7 & Sdev & 2.6 & 2.8 & 5.2 & 6.2 \\
\hline Min & -13.8 & -14.0 & 949.2 & 949.2 & Min & -7.1 & -7.3 & 979 & 974.7 \\
\hline $\operatorname{Max}$ & 3.4 & 2.5 & 1022.4 & 1011.6 & Max & 1.3 & 1.4 & 999 & 996.2 \\
\hline$n$ (events) & 372 & 136 & 356 & 135 & $n$ (events) & 14 & 14 & 14 & 14 \\
\hline
\end{tabular}

similar slopes of both lines, but lower intercept of the LMWL $(1.2 \%$ ) than that of the GMWL (Fig. 8a), indicates slightly difference of evaporation conditions in the moisture source with respect to the global average. This point will be discussed in greater detail in the following sections.

\subsubsection{Firn cores}

The most negative mean $\delta^{18} \mathrm{O}$ value $(-12 \%)$ is found for core $\mathrm{OH}-6$. The location of core $\mathrm{OH}-6$ corresponds with the highest altitude of the study area (1030 $\mathrm{m}$ a.s.1.). On the other hand, the cores $\mathrm{OH}-1, \mathrm{OH}-4$ and $\mathrm{OH}-5$ show only a slight difference in their $\delta^{18} \mathrm{O}$ mean, and precipitation $\delta^{18} \mathrm{O}$ mean values, despite the altitude differences between the coring locations. This implies that an isotopic altitude effect is visible only above $600 \mathrm{~m}$ a.s.1. (i.e. between the location of OH-5 and $\mathrm{OH}-6)$. Unfortunately no direct comparison within the cores from FP is possible, since only 2 of the 3 cores are suitable but located too closely to each other, thus no altitude effect is visible. Co-isotope $\delta D / \delta^{18} \mathrm{O}$ diagrams of the cores allow us to compare the precipitation and firn samples, similar to the LMWL explained in Sect. 4.1.1. From Fig. 8b, it is observed that all firn cores have a slope close to 8 and intercepts between 0.4 and 4 , and are therefore quite similar to the precipitation LMWL (below the GMWL). From these observations, it can be derived that (1) the fractionation during the condensation process is common for the whole region, and (2) that post-depositional effects (e.g. diffusion and/or sublimation) do not play an important role for the snow/firn isotopic composition of the area. It is widely accepted that annual $\delta^{18} \mathrm{O}$ and $\delta D$ maxima (minima) occur in summer (winter) coincident with highest (lowest) air tem- perature in the southern high latitudes. The counting of alternation of these peaks is the most common method used for dating of firn and ice in regions with high accumulation (Legrand and Mayewski, 1997). However, this is not an easy task in our study area. As seen in Table 1, all firn cores below $600 \mathrm{~m}$ a.s.l. show a strong smoothing of the isotopic signal that can be visualized from the $\delta^{18} \mathrm{O}$ and $\delta D$ standard deviation values ( $\left.\sigma_{\text {cores }}\right)$, caused by the summer melt of the surface snow and firn. The $\sigma_{\text {cores }}$ for both FP and $\mathrm{OH}$ locations are clearly dependent on the altitude, with constrained $\sigma_{\text {cores }}$ for the cores in lower altitudes and increasing $\sigma_{\text {cores }}$ in high locations. Moreover, the deviation of the isotope composition of OH-6 $(\sigma=2.5)$ is almost identical to that of $\mathrm{OH}$ precipitation $(\sigma=3.3)$, pointing out that at this location, melt is absent or strongly reduced. These observations are also confirmed by the visual inspection of the firn cores $\mathrm{OH}-1, \mathrm{OH}-$ 4, FP-3 and FP-4, which displays several ice layers caused by melt and refreezing up to several centimeters thick. In the case of these cores retrieved closer to the coast, the infiltration and refreezing is especially strong with up to $0.5 \mathrm{~m}$ thick melt/refreeze sections. In contrast, the core OH-6 does not show any major ice layers. The few ice layers in this core are all less than $1 \mathrm{~cm}$ thick and rather represent windglazed crusts. An exception was observed at around $0.5 \mathrm{~m}$ depth (snow) where a clear melt-refreeze ice layer is visible with a thickness of around $2 \mathrm{~cm}$. This layer has a clearly defined upper surface, and was then covered by snow. Despite of the fact that the cores above $600 \mathrm{~m}$ a.s.l. (FP-1, OH-5 and especially $\mathrm{OH}-6$ ) are most likely not (or only rarely) affected by melt-percolation processes, no clear seasonality in the $\delta^{18} \mathrm{O}(\delta D)$ record can be seen (Fig. 9). Thus, the dating and estimation of accumulation rate is not a straight forward 

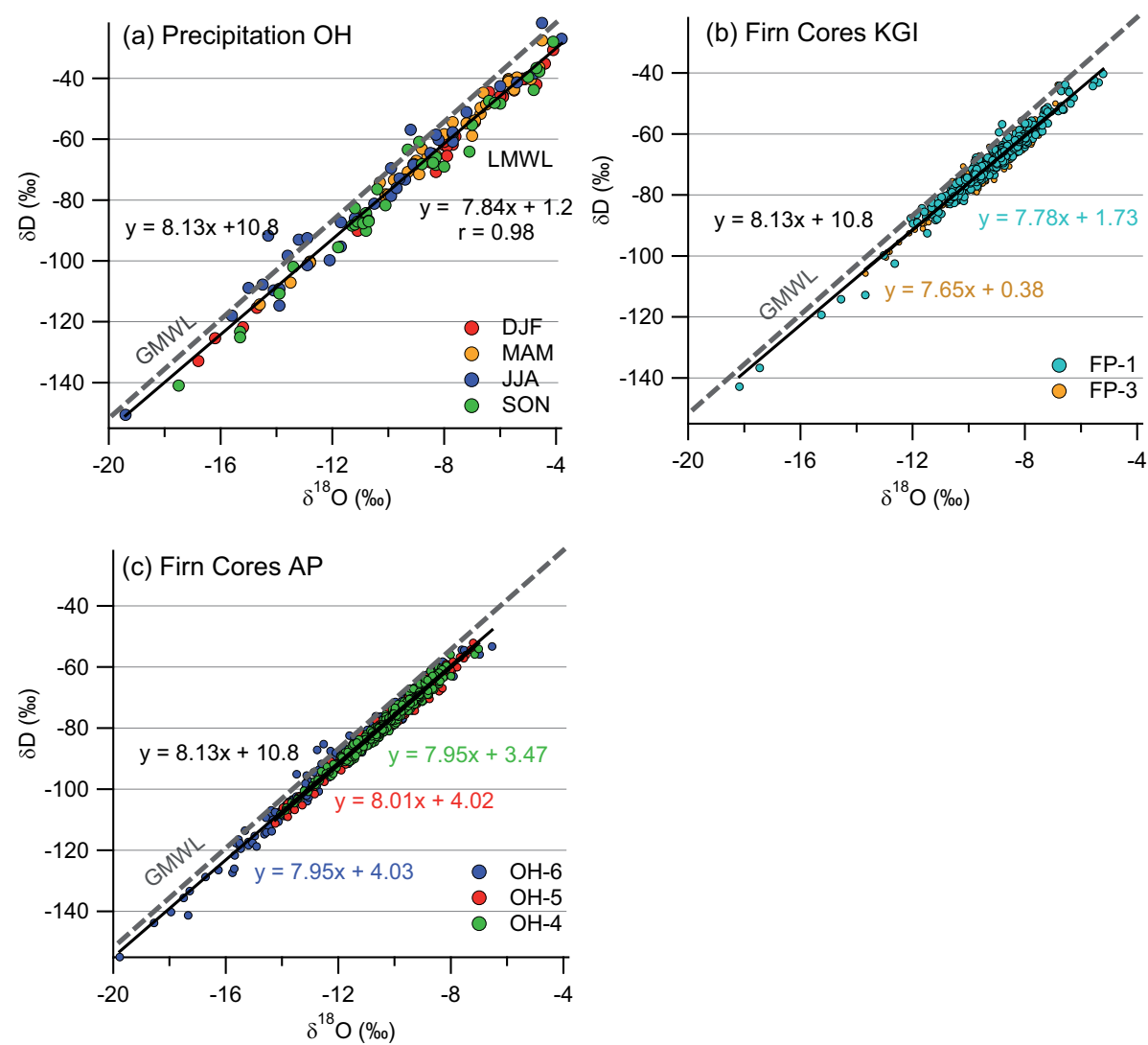

Fig. 8. Co-isotope relationships for: (a) Precipitation samples collected in O'Higgins showing the Local Meteoric Water Line (LWML) defined for this location (black line), (b) Firn cores retrieved from King George Island (FP cores) and (c) firn cores from the Antarctic Peninsula $(\mathrm{OH})$. For all correlations the equation of the best linear fit is presented, additionally the Global Meteoric Water Line (GMWL) is shown for all three figures (dashed grey line).

procedure. The explanation for this feature is linked to the meteorology of the region, with restricted seasonal temperature oscillations. Sime et al. (2009), described that the $\delta^{18} \mathrm{O}(\delta D)$ signal reflects only between $11 \%$ and $30 \%$ of the MAAT for the James Ross Island area, north-east Antarctic Peninsula (Fig. 1). The isotope/temperature relation varies along the Antarctic Peninsula improving to the south-west (explaining up to $70 \%$ of local MAAT variation), depending on local daily, synoptic and seasonal atmospheric and meteorological characteristics. The isotope seasonality signal of our study region is further discussed in the following deuterium excess section.

\subsection{Deuterium excess}

Here, we present and discuss the results of the highresolution measurements of $d_{\text {excess }}$ calculated from $\delta^{18} \mathrm{O}$ and $\delta D$ values.

\subsection{1 $d$ excess of precipitation}

From all 139 samples collected at $\mathrm{OH}$ between February 2008 and March 2009 single $d_{\text {excess }}$ values have been calculated (Fig. 10). A mean $d_{\text {excess }}$ value of $2.7 \%$ (Table 2) suggests that the evaporation of the moisture reaching this station occurs in conditions of relatively high $h$, most probably with origin in the adjacent Southern Ocean. According to the relationship defined by Uemura et al. (2008): $d=-0.61 h+55.7$, the evaporation of moisture that arrives at $\mathrm{OH}$ should occur under conditions of $\sim 87 \%$ relative humidity, close to the global mean of $85 \%$ (Clark and Fritz, 1997) calculated for the GMWL of Craig (1961) and the GNIP data base (available at: http://www-naweb.iaea.org/ napc/ih/index.html) (Rozanski et al., 1993). The disagreement between global mean values and precipitation at $\mathrm{OH}$ (contrasting $d_{\text {excess }}$ but similar $h$ ), indicates that the use of the GMWL for Antarctic coastal regions is not precise, since evaporation and condensation occurs under different conditions than those from tropical and sub-tropical regions. Therefore, we introduce a local MWL, which should better fit for these purposes. Daily $d_{\text {excess }}$ values are shown in Fig. 10, displaying a large variability, especially in winter. A very similar, but inverse pattern is seen for the $T_{\text {air }}$ (Fig. 10, light grey line), therefore suggesting that local $T_{\text {air }}$ controls the $d_{\text {excess }}$ variability. This is a substantial observation of 

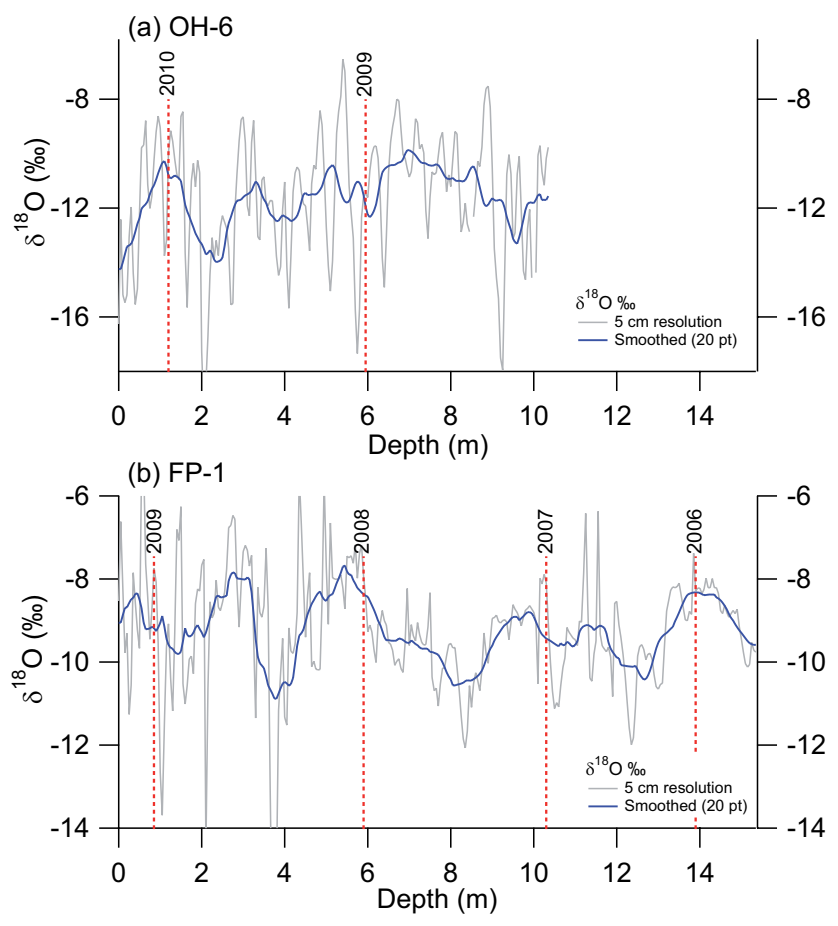

Fig. 9. High resolution $(5 \mathrm{~cm}$, light grey lines) and smoothed (20 points, blue line) $\delta^{18} \mathrm{O}$ signal of firn cores: (a) OH-6 and (b) FP1. OH-6 was retrieved from Laclavere Plateau (Antarctic Peninsula) in 2010; FP-1 was retrieved from the main dome of King George Island (South Shetland Islands), in 2009. Note that none of the cores show defined seasonal cycles, as seen from the year of deposition. The first day of the year is approximately indicated (dashed red lines).

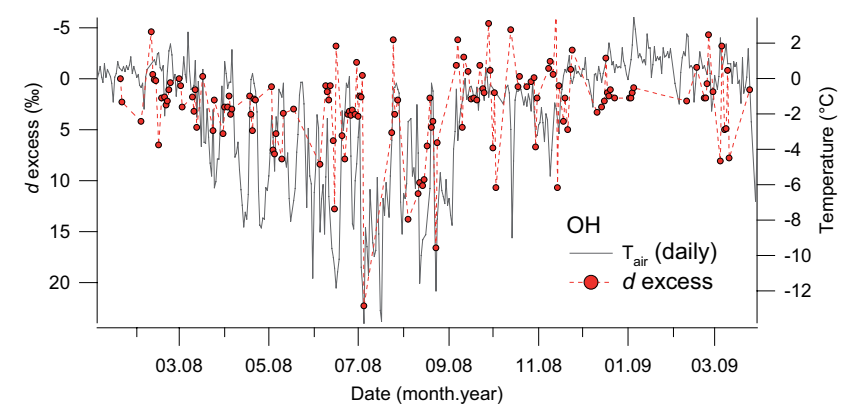

Fig. 10. $d_{\text {excess }}$ (red dots) values of daily precipitation samples collected at O'Higgins stations and daily air temperature record (light grey lines) from this station. For visualization purposes the $d_{\text {excess }}$ axis has been inverted.

this investigation, because: (1) this gives the possibility to use the $d_{\text {excess }}$ variability as geochemical proxy for local $T_{\text {air }}$ and (2) the synchronous (inverse) variation of $T_{\text {air }}$ and $d_{\text {excess }}$ implies that the moisture source should be located relatively near, since a longer path of moisture masses arriving at $\mathrm{OH}$, will cause a lag on $T_{\text {air }}-d_{\text {excess }}$ oscillations. Furthermore, the single events reveal that $d_{\text {excess }}$ is a good indicator of ex-

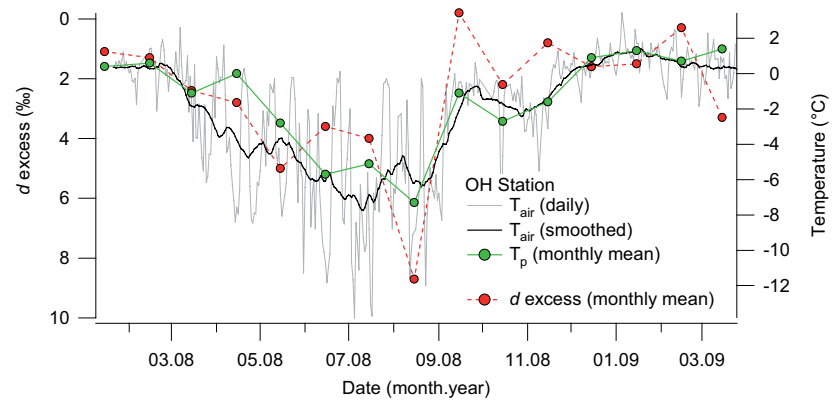

Fig. 11. Monthly $d_{\text {excess }}$ mean (red dots) of precipitation samples from O'Higgins station and daily air temperature ( $T_{\text {air }}$, light grey). The smoothed $T_{\text {air }}$ (black line) correspond to a 30 day running mean function. For visualization purposes the $d_{\text {excess }}$ axis has been inverted.

treme meteorological conditions, as observed in fast drops of $T_{\text {air }}$, e.g. on 4 July $\left(T_{\mathrm{p}}=-14^{\circ} \mathrm{C}\right), 5$ August $\left(T_{\mathrm{p}}=-9^{\circ} \mathrm{C}\right)$ and 23 August $\left(T_{\mathrm{p}}=-12^{\circ} \mathrm{C}\right)$ reflected in a strong increase of $d_{\text {excess }}(22.3 \% o, 13.8 \% o$ and $14.6 \%$ ), respectively (Fig. 10), which is characteristic for input of Antarctic continentally originated moisture. The increase of $d_{\text {excess }}$ has been related to changes in the fractionation rates at extreme low temperatures and to the kinetic fractionation produced by the icecrystal formation from super-cooled air masses. This effect is mainly visible above $2000 \mathrm{~m}$ a.s.l. (Jouzel and Merlivat, 1984; Masson-Delmotte et al., 2008). Nonetheless, the general negative correlation of daily $d_{\text {excess }}$ values and $T_{\mathrm{p}}$ is relatively low $(r=-0.42, p<0.01)$, due to the instability of meteorological conditions. This correlation greatly improves on a monthly to seasonal scale, as for $\delta^{18} \mathrm{O}$, mostly because the extreme and fast changes in temperature are smoothed, revealing a more realistic relationship between $d_{\text {excess }}$ and $T_{\text {air }}$ (and $T_{\mathrm{p}}$ ). The winter temperature drop of the precipitation site is then linked with an increase of $d_{\text {excess. }}$. The physical explanation is most likely the decrease of $h$ and/or SST at the moisture source. Figure 11 shows a summary of the monthly mean values of $d_{\text {excess }}, T_{\text {air }}$ and $T_{\mathrm{p}}$. Linear regressions demonstrate that the correlation coefficients $(r)$ are high between both, $T_{\text {air }}$ and $T_{\mathrm{p}}$ relative to $d_{\text {excess }}$ values. Regressions and $r$ are given for monthly mean values by the expressions:

$d=1.54-0.54 T_{\text {air }} \quad(r=-0.61, \quad p<0.01)$

and

$d=1.73-0.59 T_{\mathrm{p}} \quad(r=-0.72, \quad p<0.01)$

The linear regression equations demonstrate that the isotopic composition of precipitation from this region reflects most of the meteorological variability at seasonal and even subseasonal scales. Therefore, we conclude that the isotope composition of precipitation represent a suitable proxy for $T_{\text {air }}$ and climate parameters reconstruction. 
Table 4. Correlation matrix of mean monthly isotope values: resample of the high altitude firn cores (OH-6 and FP-1), precipitation (OH) and major seasonal forcing of meteorological variability identified for this region $\left(T_{\text {air }}-\right.$ air temperature, SIF - sea ice fraction, SST - sea surface temperature, and $h$-relative humidity). Significant p-level $(p<0.05)$ are marked in red letters.

\begin{tabular}{lrrrrrr}
\hline & $T_{\text {air }}$ OH & $T_{\text {air }}$ FP & SIF & SST & \multicolumn{2}{c}{$h$} \\
\hline FP-1 & & & & & & \\
\hline$\delta^{18} \mathrm{O}$ & 0.39 & 0.35 & -0.03 & 0.32 & 0.28 & $n=42$ \\
& $p=0.01$ & $p=0.02$ & $p=0.84$ & $p=0.04$ & $p=0.08$ & \\
$d_{\text {excess }}-0.66$ & -0.73 & 0.52 & -0.61 & -0.71 & \\
& $p=0.00$ & $p=0.00$ & $p=0.00$ & $p=0.00$ & $p=0.00$ & \\
\hline OH-6 & & & & & & \\
\hline${ }^{18} \mathrm{O}$ & 0.06 & 0.00 & -0.11 & 0.02 & -0.15 & $n=23$ \\
& $p=0.77$ & $p=1.00$ & $p=0.63$ & $p=0.94$ & $p=0.49$ & \\
$d_{\text {excess }}$ & -0.59 & -0.61 & 0.76 & -0.72 & -0.34 & \\
& $p=0.00$ & $p=0.00$ & $p=0.00$ & $p=0.00$ & $p=0.11$ & \\
\hline OH & & & & & & \\
\hline$\delta^{18} \mathrm{O}$ & 0.70 & 0.84 & -0.77 & 0.71 & 0.64 & $n=14$ \\
& $p=0.01$ & $p=0.00$ & $p=0.00$ & $p=0.01$ & $p=0.02$ & \\
$d_{\text {excess }}$ & -0.59 & -0.70 & 0.49 & -0.32 & -0.78 & \\
& $p=0.03$ & $p=0.01$ & $p=0.09$ & $p=0.29$ & $p=0.00$ & \\
\hline & & & & & &
\end{tabular}

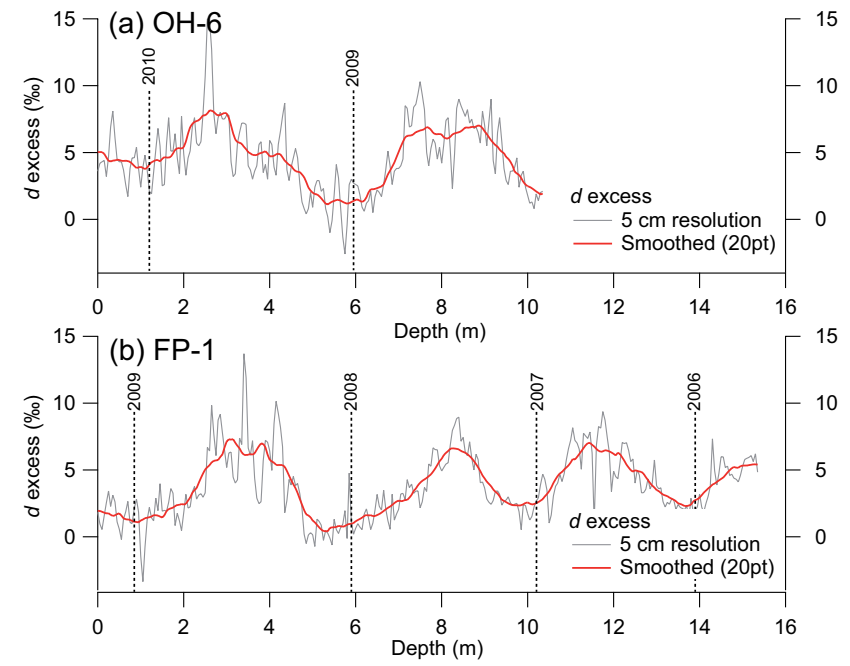

Fig. 12. Firn cores $d_{\text {excess }}$ high resolution ( $5 \mathrm{~cm}$ samples, red line) and smoothed (20 points, red line) signal of: (a) OH-6, retrieved in January 2010 at the Laclavere Plateau (Antarctic Peninsula); and (b) FP-1, retrieved in January 2009 at the main dome of King George Island (South Shetland Islands). A clear seasonality is visible for both cores, however a decrease of the amplitude is observed for the core FP-1 in depth, showing some post-depositional effects. The deposition year of firn for both cores are shown (black dashed lines - approximately the first day of the year).

\subsubsection{Deuterium excess of firn cores}

The $d_{\text {excess }}$ of most of the firn cores show mean values close to $4 \%$ (Table 1 ), with values around $1.3 \%$ above the mean $d_{\text {excess }}$ value for precipitation $(\mathrm{OH}=2.7 \%$ ) , an exception are the cores OH-1 and FP-4 ( $d_{\text {excess }}$ of $1.2 \%$ and $2.2 \%$, respectively). Despite the slight difference between $\mathrm{OH}$ station and firn $d_{\text {excess }}$ values, both are clearly under the GMWL $\left(d_{\text {excess }}=10 \%\right.$ ). At this step, some influence of moisture of continental provenance cannot be discarded for high altitude locations of KGI and API. As demonstrated above, both high-altitude cores (OH-5, OH-6 and FP-1) do not indicate major signs of melting and/or percolation. Furthermore OH-6 show the highest $d_{\text {excess }}$ value of all cores $(4.4 \%$ ). Thus, the $d_{\text {excess }}$ values in high altitude locations could reflect a slightly different moisture composition as compared to the coastal area. Moreover, at both areas (OH and $\mathrm{KGI})$ the $d_{\text {excess }}$ of the cores systematically decreases towards low altitudes. Therefore, the $d_{\text {excess }}$ difference between firn cores and precipitation values is likely not to be related to postdepositional effect. Additionally, melt and/or infiltration of lower $d_{\text {excess }}$ (summer) precipitation can be discarded as the main cause of the lower values with decreasing altitude, since $d_{\text {excess }}$ of OH-1 (220 m a.s.1.) is similar to that of precipitation at $\mathrm{OH}$ station. As previously mentioned, at this station year-round well distributed precipitation events were sampled and a seasonal bias of isotope composition can for this reason be rejected. Other local effects like diffusion within the snow cover or preferential removal of low $d_{\text {excess }}$ layers cannot be ruled out without direct observations (e.g. wind 


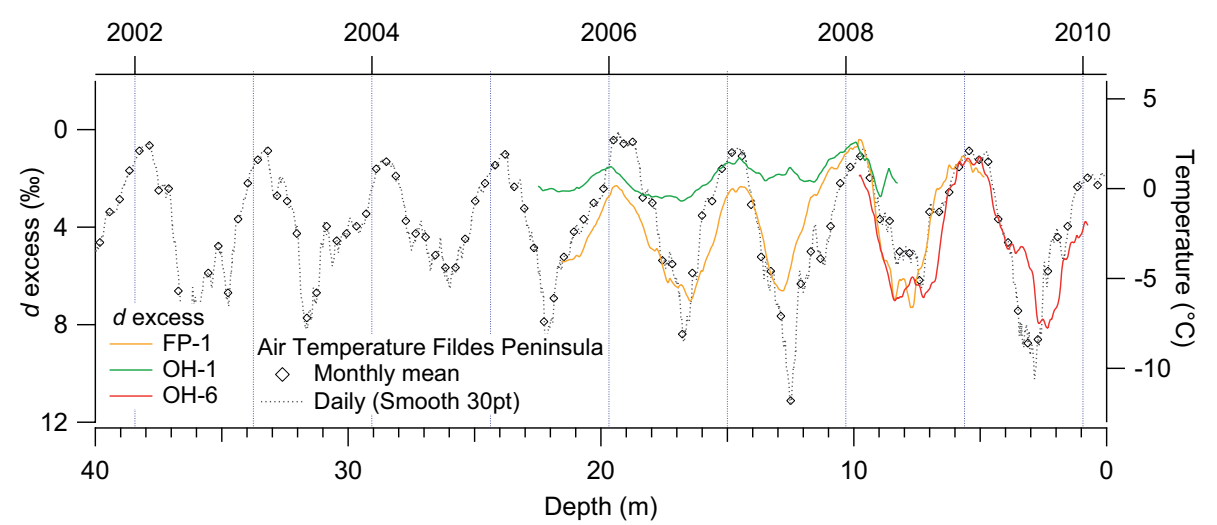

Fig. 13. Seasonality of $d_{\text {excess }}$ presented by three firn cores: FP-1 (King George Island), OH-1 and OH-6 (Antarctic Peninsula). The cores were retrieved in different field campaigns during 2008 and 2010, therefore the depth axis is only referential, note as well that the $d_{\text {excess }}$ axis has been inverted for better comparison of the data. Air temperature (dashed black line and diamonds) is from Bellingshausen Station, Fildes Peninsula (King George Island). The first day of the year is represented by the vertical lines.

drift or sublimation), but these have been considered to be not significant for the API region, due to the high precipitation rates, and therefore not having a great impact on the isotope composition (van Lipzig et al., 2004). The comparison of the $d_{\text {excess }}$ standard deviation $\left(\sigma_{\text {excess }}\right)$ of firn cores and precipitation demonstrate that closer to the coast firn displays a strong homogenization of the isotope composition, where $\sigma_{\text {excess }}$ for $\mathrm{OH}$ station $\left(\sigma_{\text {excess }}=2.7\right)$ is clearly larger than coastal cores OH-1 $\left(\sigma_{\text {excess }}=0.8\right)$ and FP-4 $\left(\sigma_{\text {excess }}=0.6\right)$. Larger values of $\sigma_{\text {excess }}$ are found only at the high altitudes regions ( $>600 \mathrm{~m}$ a.s.l.) of $\mathrm{OH}$ and FP (see Table 1). Lower $d_{\text {excess }}$ values, as mentioned above, are associated with more humid conditions at the moisture source. This supports the assumption that the coastal regions are influenced by a stronger maritime regime, which slightly decreases towards the higher altitudes. Similar to the observed seasonal variations of the $\mathrm{OH}$ data, the $d_{\text {excess }}$ of firn cores presents a marked seasonality (Fig. 12), hence allowing the use of the $d_{\text {excess }}$ seasonal variability as an instrument for dating of the accumulated snow and firn. In Fig. 13, the smoothed $d_{\text {excess }}$ of cores OH-6, OH-1 and FP-1 are compared to the $T_{\text {air }}$ from FP. The smoothing of the $d_{\text {excess }}$ signal was done using a special moving average function (box function), considering a similar number of points before and after the smoothed value (21 points, $\sim 1 \mathrm{~m}$ firn depth). In this case the FP record has been used because of gaps in the monthly and daily meteorological record of $\mathrm{OH}$ station during some periods between 2005 and 2010. This visual comparison underlies a correlation between $T_{\text {air }}$ and $d_{\text {excess. }}$. Moreover, assuming that accumulation is approximately constant through all seasons, resampling to monthly means of the isotope data of firn cores can be performed. This allows a direct comparison of monthly $T_{\text {air }}$ and $d_{\text {excess }}$ values (monthly re-sampled). Correlation coefficients for monthly means are given in Table 4. Additionally, the $\delta^{18} \mathrm{O}$ resampled value is presented for comparison, reaffirming the complexity to directly in- fer $T_{\text {air }}$ from oxygen and deuterium data. From the generated age model, it can be preliminarily concluded that both locations have high accumulation rates. Wen et al. (1998) and Simões et al. (2004) retrieved ice cores from the main plateau area at KGI during different field seasons. Density of snow/firn of these cores show a compaction with an approximately linear tendency in the first $20 \mathrm{~m}$ and an increase step of $4.5 \mathrm{~kg} \mathrm{~m}^{-3}$ per meter, the surface snow density is estimated to be around $490 \mathrm{~kg} \mathrm{~m}^{-3}$. Using these density profiles combined with our age model of FP-1, accumulation rates of 2542,2296 and $1935 \mathrm{~kg} \mathrm{~m}^{-2} \mathrm{a}^{-1}$ are estimated for 2008 , 2007 and 2006, respectively for this location. These rates are similar to the mean accumulation of $2480 \mathrm{~kg} \mathrm{~m}^{-2} \mathrm{a}^{-1}$ described by Wen et al. (1998), but much higher than accumulation rates calculated by Simões et al. (2004) of about $590 \mathrm{~kg} \mathrm{~m}^{-2} \mathrm{a}^{-1}$. However, the snow/firn cover of KGI includes several ice layers, which are the product of percolation and refreezing. These may lead to overestimated density values, which would therefore correspond to higher accumulation rates. In general, the Antarctic coast exhibits elevated accumulation rates (van den Broeke et al., 2006; MassonDelmotte et al., 2008). Hence, we conclude that Simões et al. (2004) underestimated the accumulation rates of this location.

\subsection{Main $\delta$ and $d$ excess forcing}

In the preceding sections the relationship of stable water isotopes and $T_{\text {air }}$ has been largely discussed. Nonetheless, correlation coefficients for this relationship are in some cases statistically significant although with relatively low significance. The relationship between $\delta^{18} \mathrm{O}(\delta D)$ from firn cores and $T_{\text {air }}$ is complicated, and probably suitable only to study inter-annual variability; in contrast monthly $\delta^{18} \mathrm{O}$ means from precipitation events may reproduce well the $T_{\text {air }}$ variability. On the other hand $d_{\text {excess }}$ (from cores and 


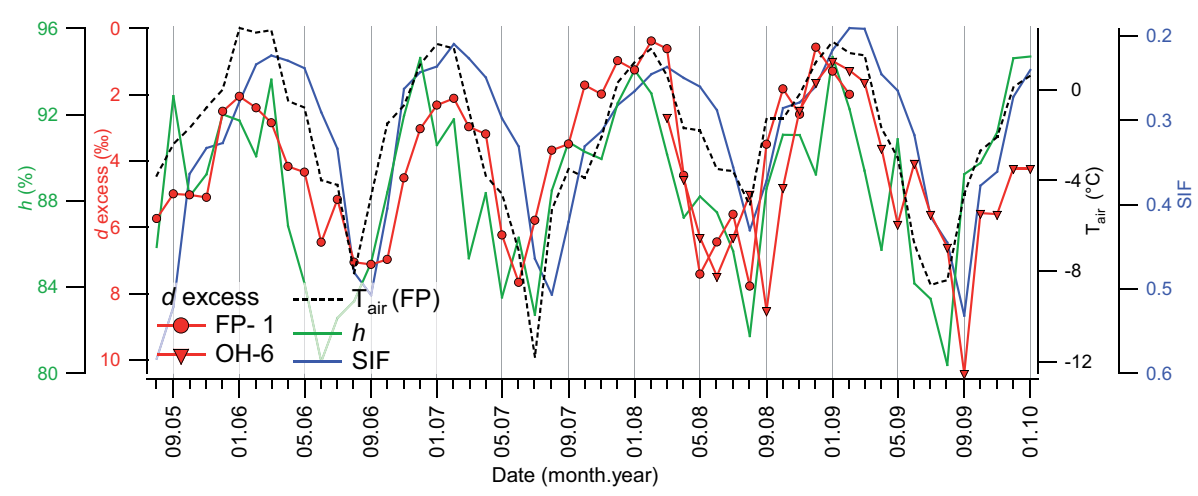

Fig. 14. Seasonal variation of monthly means of $d_{\text {excess }}$ of cores FP-1 and OH-6 compared to the meteorological variables: relative humidity ( $h$, green line), $T_{\text {air }}$ Bellingshausen station (FP, dashed black line) and sea ice fraction (SIF, blue line) for the Bellingshausen Sea. Note that the $d_{\text {excess }}$ and SIF axes are inverted for visualization purposes.

Table 5. Correlation matrix of monthly isotope means of firn core FP-1 and OH-6 (resample values) and precipitation from $\mathrm{OH}$ station for the 12 months common period (March 2008 to March 2009). Significant $\mathrm{p}$-level $(p<0.05)$ are marked in red for easy recognition.

\begin{tabular}{lrrrrrr}
\hline & \multicolumn{2}{c}{ FP-1 } & & \multicolumn{2}{c}{ OH-6 } & \\
\cline { 2 - 3 } \cline { 5 - 6 } OH Prec & $\delta^{18} \mathrm{O}$ & $d_{\text {excess }}$ & & $\delta^{18} \mathrm{O}$ & $d_{\text {excess }}$ & \\
\hline$\delta^{18} \mathrm{O}$ & 0.06 & -0.74 & & -0.42 & -0.72 & $n=12$ \\
& $p=0.85$ & $p=0.01$ & & $p=0.17$ & $p=0.01$ & \\
$d_{\text {excess }}$ & 0.14 & 0.76 & & -0.12 & 0.30 & \\
& $p=0.66$ & $p=0.00$ & & $p=0.71$ & $p=0.35$ & \\
\hline
\end{tabular}

\begin{tabular}{lrrrrr}
\hline FP-1 & & & & & \\
\hline$\delta^{18} \mathrm{O}$ & 1.00 & -0.05 & -0.11 & -0.23 & $n=12$ \\
& $p=-$ & $p=0.88$ & $p=0.73$ & $p=0.47$ & \\
$d_{\text {excess }}$ & -0.05 & 1.00 & 0.03 & 0.69 & \\
& $p=0.88$ & $p=-$ & $p=0.92$ & $p=0.01$ & \\
\hline
\end{tabular}

\begin{tabular}{lrrrrr}
\hline OH-6 & & & & & \\
\hline$\delta^{18} \mathrm{O}$ & -0.11 & 0.03 & 1.00 & 0.05 & $n=12$ \\
& $p=0.73$ & $p=0.92$ & $p=-$ & $p=0.87$ & \\
$d_{\text {excess }}$ & -0.23 & 0.69 & 0.05 & 1.00 & \\
& $p=0.47$ & $p=0.01$ & $p=0.87$ & $p=-$ & \\
\hline
\end{tabular}

precipitation) turns out to be suitable to study the regional climatic variability, because it does not directly depend on local conditions. The synchronicity of $T_{\text {air }}$ and $d_{\text {excess }}$ variation, with absolute low $d_{\text {excess }}$ values, suggest a (humid) nearby oceanic source of the moisture precipitating at the study region. The $d_{\text {excess }}$ depends primarily on the $h$ and SST of the moisture source, moreover $h$ and SST seasonal oscillation are linked and influenced by the sea ice cover. During winter, the sea ice cover can obstruct the contact between the water surface and atmosphere, therefore influencing $T_{\text {air }}$, $h$ and SST. Weatherly et al. (1991) proved the interdependency of $T_{\text {air }}$ and sea ice cover, acting as inverse feed-back mechanisms of each other, i.e. an extended sea ice cover in winter will cause a decrease of $T_{\text {air }}$, and on the other hand $T_{\text {air }}$ in summer will predispose the following season's sea ice genesis. This mechanism is strong at the API region, since most of the local oceanic moisture is transported by the westerlies and then trapped by the natural barrier of the API range; therefore directly influencing the isotope composition of coastal precipitations. Similar conclusion on the effect of sea ice over the isotope composition of moisture were drawn by Noone and Simmonds (2004), recognizing the potential of water isotope (particularly the $d_{\text {excess }}$ ) for paleo-climate reconstruction. In our study, the local isotope variability is evaluated for $T_{\text {air }}$, SST, $h$ and sea ice cover (expressed as $\mathrm{SIF})$ as the main drivers of the seasonal to sub-seasonal isotope composition of moisture masses (Fig. 14). Table 5 displays a correlation matrix for $\delta^{18} \mathrm{O}$ and $d_{\text {excess }}$ values of two firn cores (OH-6 and FP-1) monthly resample and of monthly mean precipitation, compared with the meteorological time series. High correlation coefficients are found for $d_{\text {excess }}$ of both firn cores with $T_{\text {air }}$ from FP and $\mathrm{OH}$ stations (note that the $\mathrm{OH}$ station shows slighter lower coefficients probably related to the data gaps of the time series). As expected from our previous observations $\delta^{18} \mathrm{O}$ from firn cores do not correlate well with $T_{\text {air }}$. However, SIF, SST and $h$ time series correlate fairly well to the $d_{\text {excess }}$ of both cores, confirming the dependency of the isotope composition from the moisture source conditions. The only exception to this assumption is the firn core OH- 6 , where the $h / d_{\text {excess }}$ correlation coefficient is low and not significant. Nevertheless, this is forced by two high $d_{\text {excess }}$ values, because of the low number of observations $(n=23)$. High $d_{\text {excess }}$ values most likely do not represent oceanic moisture and are linked to more continental influenced moisture. If these two peaks are removed, the correlation improves to $r=-0.46$ and becomes significant at p-level $<0.05$. Moreover, a spatial correlation analysis of $d_{\text {excess }}$ and surface air temperature was carried out. To compute the spatial correlation, a longer $d_{\text {excess }}$ time series was generated by compositing FP-1 and OH-6 monthly means, 
Table 6. Seasonal frequencies (in percentage) of the backward trajectory clusters calculated from single events at $\mathrm{OH}$ station. The right column indicates the number $(n)$ of single events recorded in each season.

\begin{tabular}{lrrrrr}
\hline & \multicolumn{5}{c}{ Cluster } \\
\cline { 2 - 5 } & 1 & 2 & 3 & 4 & $n$ \\
\hline DJF & $21.2 \%$ & $24.2 \%$ & $51.5 \%$ & $3.0 \%$ & 33 \\
MAM & $21.2 \%$ & $12.1 \%$ & $60.6 \%$ & $6.1 \%$ & 33 \\
JJA & $28.6 \%$ & $45.7 \%$ & $5.7 \%$ & $20.0 \%$ & 35 \\
SON & $29.4 \%$ & $32.4 \%$ & $29.4 \%$ & $8.8 \%$ & 34 \\
\hline
\end{tabular}

this was analyzed against air temperature at surface level at each NCEP grid point around the Antarctic Peninsula, Drake Passage and Valdes Peninsula. Since each grid point was a single time series, which allowed us to create a map of spatial correlation (Fig. 15) with a single correlation coefficient to each lat-lon point. The analysis shows a significant correlation of $d_{\text {excess }}$ with the surface air temperature especially from the Bellingshausen Sea and Drake Passage area. Furthermore, it is important to note the higher correlation of $d_{\text {excess }}$ with the Atlantic Ocean sector than the Pacific side. $\mathrm{OH}$ monthly mean $\delta^{18} \mathrm{O}$ and $d_{\text {excess }}$ of precipitation correlate very well to $T_{\text {air }}$ from both stations with a very high correlation coefficient with respect to FP station. The relationship between isotope composition and SIF, SST and $h$ is more complicated to interpret since the number of valid observations is very restricted. In any case again the correlation between $h$ and $d_{\text {excess }}$ remains strong. On the other hand, several studies show that NCEP/NCAR reanalysis overestimate some of the meteorological parameters (Hines et al., 2000; Smith et al., 2001). From our observation a relative humidity for the moisture source of about $84 \%$ (cores OH- 6 and FP1) to $87 \%$ (OH precipitation) was estimated. NCEP/NCAR reanalysis for the corresponding locations and time periods estimates a slightly higher $h=89 \%$ for all cases. The intercomparison between the two different locations with respect to the precipitation samples in a common time-span (Table 5), i.e. the period of common overlap of the two firn cores and precipitation collection (12 months in total, March 2008 to March 2009), allows to test the strength of the regional isotope signal. The $\delta^{18} \mathrm{O}$ correlation for the firn cores and precipitation shows no coherent pattern, reflecting the high spatial variability of local meteorological (e.g. $T_{\text {air }}$ ) conditions. On the other hand, from this matrix is again confirmed that the $d_{\text {excess }}$ signal correlates for all data sets, with coefficients close or higher than 0.7 , reaffirming the robustness of the monthly $d_{\text {excess }}$ signal.

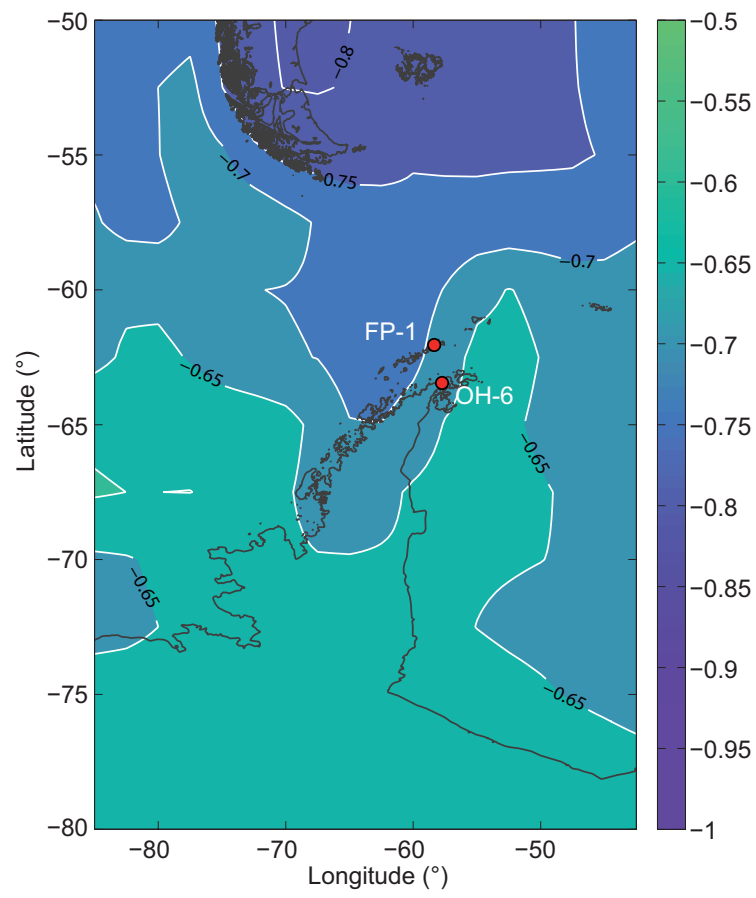

Fig. 15. Spatial correlation of the calculated $d_{\text {excess }}$ monthly mean composite from the firn cores FP-1 and OH-6 (red points) against air temperature (at surface level) from NCEP reanalysis. The color scale represents the correlation coefficient $(r)$.

\section{Backward trajectory model}

With the objective to further investigate the (physical) source of moisture masses that arrive to the study area, the air parcels circulation model Hysplit (Draxler and Hess, 1998) (available at: http://www.arl.noaa.gov/ready/hysplit4.html) has been used to reconstruct a 3-day backward circulation path of every single precipitation event registered at $\mathrm{OH}$ station arriving at $1500 \mathrm{~m}$ a.s.1. ( $850 \mathrm{mb}$ approximately). Figure 16a presents a frequency chart of all paths that arrived during daily precipitation events between February 2008 and March 2009 (139 events). This figure shows a wide distribution of the trajectories varying in their origin from the South Pacific in the north to the Bellingshausen Sea in the south, from the east (Weddell Sea and South Atlantic) some sporadic events are seen as well. Most of the trajectories follow a clear pattern following a restricted pathway between latitudes $60^{\circ}$ and $65^{\circ} \mathrm{S}$. Following a statistical treatment, all trajectories were clustered in 4 main paths to identify the regions, from where the events preferentially originated (Fig. 16b). The statistical treatment consists of clustering the trajectories with the lower spatial variance. Initially all trajectories are considered independent clusters (as many clusters as trajectories), consecutive passes will group the two clusters with the absolute lowest spatial variance, repeating this iteration as many times as trajectories to finally calculate only one cluster and calculating a total spatial variance 


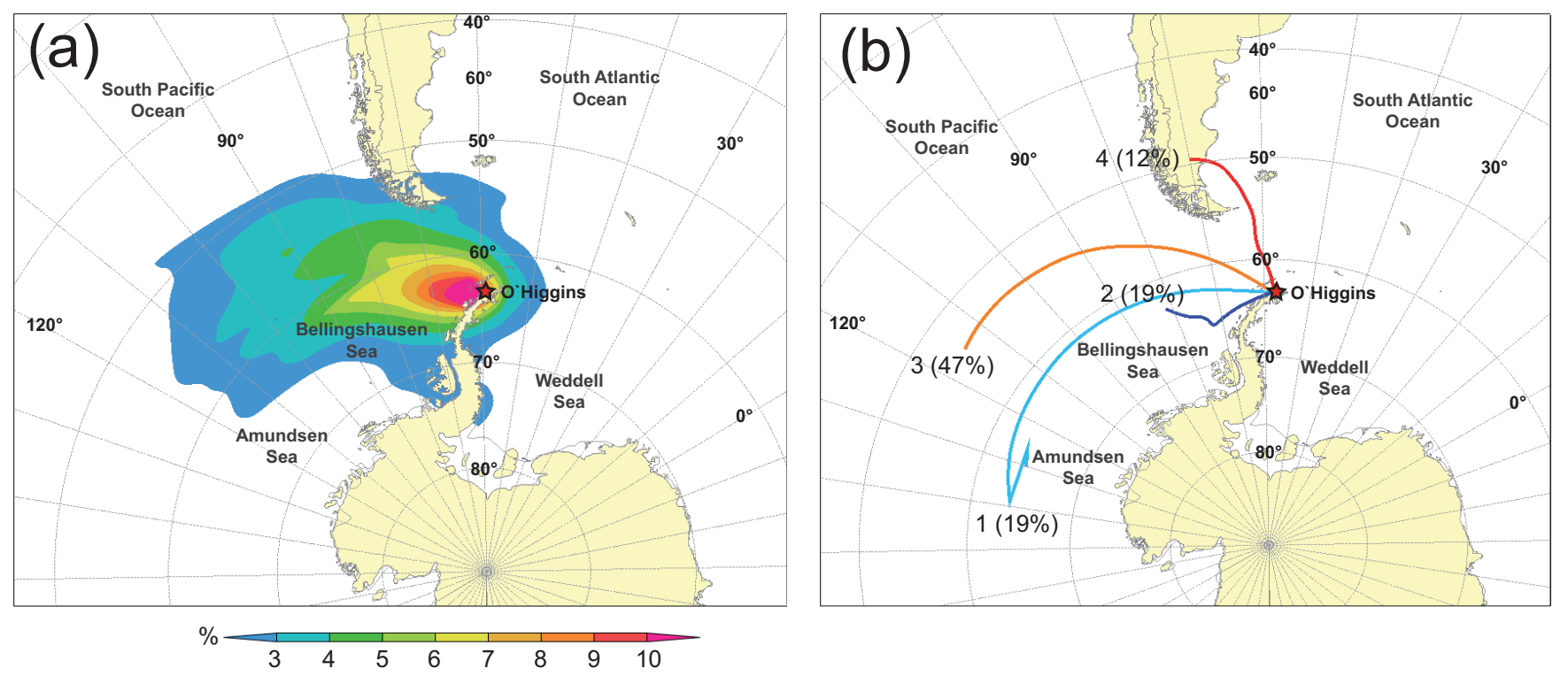

Fig. 16. Backward trajectories analysis (3-days): (a) Frequency of track of the single trajectories calculation of air parcels arriving at OH station (1500 m a.s.l. level) during precipitation events. A total of 139 single trajectories were calculated and (b) backward trajectories clustering for precipitation events at $\mathrm{OH}$ station. Four main clusters are identified, the percentage of trajectories bundled to each cluster is stated in parenthesis (cf. Table 6). From a total of 139 trajectories, 4 events are not associated to any of the clusters. The red star shows the location of O'Higgins Station.

(TSV) at each step. The optimal number of clusters is finally chosen arbitrarily observing when the TSV approached a flat maximum. For further details visit the Hysplit website (http://ready.arl.noaa.gov/HYSPLIT.php). After running the cluster analysis an optimal number of 4 clusters was recognized (Fig. 16b). The most common direction (cluster 3) is found at around $55^{\circ} \mathrm{S}(47 \%)$, followed by two southern clusters (1 and 2) that together gather almost $40 \%$ of all events originating south of latitude $60^{\circ} \mathrm{S}$ (Bellingshausen Sea). The seasonal distribution (Table 6) of the clusters reveals a migration pattern with a preferential South Pacific origin (cluster 3) in summer (DJF) and autumn (MAM), and preferential Bellingshausen Sea direction (cluster 2) in winter (JJA) and spring (SON). Later the clusters were combined with the stable water isotope information to identify difference in the composition of precipitation events under the influence of different sources. As seen in Table 7, both northern clusters (3 and 4) are composed by events with less negative $\delta^{18} \mathrm{O}$ $(\delta D)$ and tending to lower $d_{\text {excess }}$ values. The southern clusters $(1$ and 2$)$ present lower $\delta^{18} \mathrm{O}(\delta D)$ and higher $d_{\text {excess. }}$. Both southern clusters are also associated with lower temperatures and atmospheric pressures. In contrast, the cluster 3 is associated with higher temperatures and pressure. Cluster 4, the less common, represents especially high pressures containing all trajectories with an east component occurring most frequently in winter. This could reflect some influence of continental moisture or katabatic winds; however this is not reflected in the isotopic composition. Finally two main origins of the air parcels arriving at O'Higgins can
Table 7. Mean isotopic composition of backward trajectory clusters, each cluster contains $n$ single events. Temperature $\left(T_{\mathrm{p}}\right)$ and air pressure $\left(\mathrm{SLP}_{\mathrm{p}}\right)$ correspond to the precipitation day only.

\begin{tabular}{ccrrrrr}
\hline Cluster & $n$ & $\begin{array}{r}\delta^{18} \mathrm{O} \\
(\% \circ)\end{array}$ & $\begin{array}{r}\delta D \\
(\% \circ)\end{array}$ & $\begin{array}{r}d_{\text {excess }} \\
(\% \circ)\end{array}$ & $\begin{array}{r}T_{\mathrm{p}} \\
\left({ }^{\circ} \mathrm{C}\right)\end{array}$ & $\begin{array}{r}\mathrm{SLP}_{\mathrm{p}} \\
(\mathrm{mbar})\end{array}$ \\
\hline 1 & 27 & -10.2 & -78.1 & 3.2 & -2.2 & 979.4 \\
2 & 26 & -10.1 & -76.1 & 5.0 & -4.1 & 979.3 \\
3 & 65 & -8.7 & -67.8 & 1.6 & -0.9 & 983.9 \\
4 & 17 & -8.4 & -64.8 & 2.5 & -3.3 & 992.0 \\
\hline
\end{tabular}

be concluded: one between latitudes $50^{\circ} \mathrm{S}$ and $60^{\circ} \mathrm{S}$ (South Pacific), representing the most common one; and a second origin south of the latitude $60^{\circ} \mathrm{S}$ (Bellingshausen-Amundsen Sea).

\section{Conclusions}

Our results demonstrate that the combination of stable water isotope analyses with different meteorological data sets offer a valuable proxy for paleo-climate reconstruction in the north Antarctic Peninsula region. Undoubtedly, this task has been correctly recognized by previous studies as a complicated one (King and Comiso, 2003; Sime et al., 2009). Nonetheless, isotope analysis $\left(\delta^{18} \mathrm{O}\right.$ and $\left.\delta D\right)$ of precipitation samples collected in a daily schedule during 14 months (2008 to 2009) from Frei and O'Higgins stations at the northern Antarctic Peninsula, highly reflect the meteorological variability of the region. The second order 
parameter $d_{\text {excess }}$ calculated for all samples, shows to be a good indicator of air temperature variability and single extreme meteorological events (elevated $d_{\text {excess }}$ values). Moreover, mean monthly $\delta^{18} \mathrm{O}$ and $d_{\text {excess }}$ values highly correlate with air temperature oscillations. We calculated temperature gradients of $0.41 \% 0^{\circ} \mathrm{C}^{-1}(r=0.8)$ and $0.59 \% 0^{\circ} \mathrm{C}^{-1}$ $(r=0.7)$ for $\delta^{18} \mathrm{O}$ and $d_{\text {excess }}$, respectively. Several firn cores extracted from the ice caps adjacent to both stations were examined in order to study the implication of the precipitation data for the firn/ice core interpretation. From visual inspection and isotope analyses it is evident that all cores retrieved below $600 \mathrm{~m}$ a.s.l. show evidence for percolation and refreezing due to summer melt. Moreover, from the highresolution analyses $(5 \mathrm{~cm})$ several isotopic features can be recognized. The $d_{\text {excess }}$ slightly increases towards high altitudes probably reflecting a stronger influence of maritime conditions at coastal zones. The $\delta^{18} \mathrm{O}$ from firn cores does not capture well the local seasonal temperature fluctuation, as a consequence of the low seasonal temperature oscillation $\left(\sigma_{\text {air }}=3.6^{\circ} \mathrm{C}\right)$ and local post depositional effects. On the other hand the $d_{\text {excess }}$, since it does not depend on the local conditions exhibit a much better seasonality, thus allowing the dating of firn accumulated at this region. The synchronicity of $d_{\text {excess }}$ and air temperature implies a local moisture source for the precipitation arriving at this region. Low absolute $d_{\text {excess }}$ values indicate a moisture source with typical oceanic characteristics with an estimated mean relative humidity of $87 \%$, according to the relationship calculated by Uemura et al. (2008). A backward trajectory analysis (3 days backward) of all registered precipitation events show that the air masses follow two main paths before snow and/or rain falls: one from the South Pacific $\left(50^{\circ}-60^{\circ} \mathrm{S}\right)$ and a second one from the Bellingshausen-Amundsen Sea (south of $60^{\circ} \mathrm{S}$ ); the first occurring preferentially in summer-autumn and the second in winter-spring. Correspondingly the northern path shows more positive $\delta^{18} \mathrm{O}$ and lower $d_{\text {excess }}$ values, confirming that both parameters are sensitive to changes in the moisture source region. Hence, stable isotope time series of the firn cores were compared to different meteorological variables such as: SST, $h, T_{\text {air }}$, and SIF. The $d_{\text {excess }}$ show a strong correlation to humidity and sea surface temperature especially from the Bellingshausen Sea and Drake Passage area ( $r=0.7$ to 0.8 for both parameters); as well as a correlation to the sea ice cover is observed ( $r=0.5$ to 0.7 ), explained by the influence of sea ice directly on the air temperature and ocean-atmosphere interaction. Finally, the core retrieved at the Laclavere Plateau ( $1030 \mathrm{~m}$ a.s.1.), which was explored for the first time in 2010, represents very promising conditions for future glaciological investigations: restricted melt evidence of firn and snow, a high accumulation rate which ensures that a high resolution archive is stored in the ice cover, as well as low MAAT of this area estimated to be around $-10^{\circ} \mathrm{C}$. In this paper we show the potential of the stable water isotope for the interpretation and reconstruction of the climate variability of this region.
Acknowledgements. We thank the generous scientific and logistic support of several institutions to this investigation. The Instituto Antártico Chileno (INACH) is specially acknowledged for their support in the field, the Chilean Air Force, Chilean Army, and the Chilean Meteorological Service (DMC) are thanked for their logistical organization and effort, as well as the Uruguayan station Artigas and the Instituto Antártico Uruguayo (IAU). We would like to express our gratitude to M. Rückamp, S. Suckro, T. Kleiner, J. Sobiech, N. Blindow and C. Cárdenas, as well as the crew of the stations for their collaboration in the field work. Cindy Springer and Lutz Schönicke are thanked for the measurements carried out in the laboratory, as well as Mar Cartró for helping to process the data. Financial support was obtained from the DFG Project 444CHL-113/40/0-1, and the University of Concepción (Chile) DIUC internal scholarship. The PhD fellowship awarded to F. Fernandoy by the German Academic Exchange Service (DAAD) is gratefully acknowledged. We thank finally H. Oerter, T. Opel, M. Schwikowski, E. Thomas and G. Casassa for their constructive comments to this manuscript.

Edited by: G. Casassa

\section{References}

Abram, N. J., Thomas, E. R., McConnell, J. R., Mulvaney, R., Bracegirdle, T. J., Sime, L. C., and Aristarain, A. J.: Ice core evidence for a 20th century decline of sea ice in the Bellingshausen Sea, Antarctica, J. Geophys. Res., 115, D23101, doi:10.1029/2010jd014644, 2010.

Blindow, N., Suckro, S., Rückamp, M., Braun, M., Schindler, M., Breuer, B., Saurer, H., Simoes, J., and Lange, M.: Geometry and thermal regime of the King George Island ice cap, Antarctica, from GPR and GPS, Ann. Glaciol., 51, 103-109, 2010.

Bracegirdle, T. J., Connolley, W. M., and Turner, J.: Antarctic climate change over the twenty first century, J. Geophys. Res., 113, D03103, doi:10.1029/2007JD008933, 2008.

Carrasco, J. and González, M. (Eds.): Climatología de la Península Antártica y de la Base Presidente Eduardo Frei Montalva, Dirección Meteorológica de Chile, 2007.

Carrasco, J. F., Bromwich, D. H., and Monaghan, A. J.: Distribution and characteristics of mesoscale cyclones in the Antarctic: Ross Sea eastward to the Weddell Sea, Mon. Weather Rev., 131, 289301, 2003.

Chapman, W. L. and Walsh, J. E.: A Synthesis of Antarctic Temperatures, J. Climate, 20, 4096-4117, 2007.

Chen, J. L., Wilson, C. R., Blankenship, D., and Tapley, B. D.: Accelerated Antarctic ice loss from satellite gravity measurements, Nat. Geosci., 2, 859-862, 2009.

Clark, I. and Fritz, P. J. S. (Eds.): Environmental Isotopes in Hydrogeology, Lewis, Boca Raton, New York, 311 pp., 1997.

Cook, A. J., Fox, A. J., Vaughan, D. G., and Ferrigno, J. G.: Retreating Glacier Fronts on the Antarctic Peninsula over the Past HalfCentury, Science, 308, 541-544, doi:10.1126/science.1104235, 2005.

Craig, H.: Isotopic variations in meteoric waters, Science, 133, 1702-1703, doi:10.1126/science.133.3465.1702, 1961.

Dansgaard, W.: Stable isotopes in precipitation, Tellus, 16, 436468, doi:10.1111/j.2153-3490.1964.tb00181.x, 1964. 
De Angelis, H. and Skvarca, P.: Glacier Surge After Ice Shelf Collapse, Science, 299, 1560-1562, doi:10.1126/science.1077987, 2003.

Draxler, R. R. and Hess, G. D.: An Overview of the HYSPLIT4 modelling system for trajectories, dispersion and deposition, Aust. Meterol. Mag., 47, 295-308, 1998.

Gat, J. R.: Oxygen and hydrogen isotopes in the hydrological cycle, Annu. Rev. Earth Planet. Sci., 24, 225-262, doi:10.1146/annurev.earth.24.1.225, 1996.

Gillett, N., Kell, T. D., and Jones, P. D.: Regional climate impacts of the Southern Annular Mode, Geophys. Res. Lett., 33, 1-4, 2006.

Gillett, N. P., Stone, D. A., Stott, P. A., Nozawa, T., Karpechko, A. Y., Hegerl, G. C., Wehner, M. F., and Jones, P. D.: Attribution of polar warming to human influence, Nat. Geosci., 1, 750-754, 2008.

GNIP Database: http://www-naweb.iaea.org/napc/ih/index.html, last access: 2011.

Hall, B.: Holocene glacial history of Antarctica and the subAntarctic islands, Quat. Sci. Rev., 28, 2213-2230, 2009.

Hines, K. M., Bromwich, D. H., and Marshall, G. J.: Artificial surface pressure trends in the NCEP-NCAR reanalysis over the southern ocean and Antarctica, J. Climate, 13, 3940-3952, 2000.

HYSPLIT (HYbrid Single-Particle Lagrangian Integrated Trajectory) Model access via NOAA ARL READY. NOAA Air Resources Laboratory, Silver Spring, MD., available at: http:// www.arl.noaa.gov/ready/hysplit4.html, last access 2011.

Ichiyanagi, K., Numaguti, A., and Kato, K.: Interannual variation of stable isotopes in Antarctic precipitation in response to El Nino-Southern Oscillation, Geophys. Res. Lett., 29, 1001, doi:10.1029/2000g1012815, 2002.

IPCC, Solomon, S., Qin, D., Manning, M., Chen, Z., Marquis, M., Averyt, K. B., Tignor, M., and Miller, H. (Eds.): Climate Change 2007: The Physical Science Basis. Contribution of Working Group I to the Fourth Assessment Report of the Intergovernmental Panel on Climate Change, Cambridge University Press, Cambridge, United Kingdom and New York, USA, 2007.

Jouzel, J. and Merlivat, L.: Deuterium and Oxygen 18 in Precipitation: Modeling of the Isotopic Effects during Snow Formation, J. Geophys. Res-Atmos., 89, 1749-1757, 1984.

Kalnay, E., Kanamitsu, M., Kistler, R., Collins, W., Deaven, D., Gandin, L., Iredell, M., Saha, S., White, G., Woollen, J., Zhu, Y., Leetmaa, A., Reynolds, R., Chelliah, M., Ebisuzaki, W., Higgins, W., Janowiak, J., Mo, K. C., Ropelewski, C., Wang, J., Jenne, R., and Joseph, D.: The NCEP/NCAR 40-Year Reanalysis Project, Bulletin of the American Meteorological Society, 77, 437-471, doi:10.1175/15200477(1996)077<0437:TNYRP>2.0.CO;2, 1996.

Kanamitsu, M.: Description of the NMC Global Data Assimilation and Forecast System, Weath. Forecast., 4, 335-342, doi:10.1175/1520-0434(1989)004<0335:DOTNGD>2.0.CO;2, 1989.

King, J. C. and Comiso, J. C.: The spatial coherence of interannual temperature variations in the Antarctic Peninsula, Geophys. Res. Lett., 30, 1040, doi:10.1029/2002g1015580, 2003.

Legrand, M. and Mayewski, P.: Glaciochemistry of polar ice cores: A review, Rev. Geophys., 35, 219-243, 1997.

Levitus, S., Antonov, J., and Boyer, T.: Warming of the world ocean, 1955-2003, Geophys. Res. Lett., 32, L02604, doi:10.1029/2004g1021592, 2005.
Marshall, G. J.: Trends in the Southern Annular Mode from observations and Reanalyses, J. Climate, 16, 4134-4143, 2003.

Marshall, G. J., Orr, A., van Lipzig, N. P. M., and King, J. C.: The Impact of a Changing Southern Hemisphere Annular Mode on Antarctic Peninsula Summer Temperatures, J. Climate, 19, 5388-5404, 2006.

Masson-Delmotte, V., Hou, S., Ekaykin, A., Jouzel, J., Aristarain, A., Bernardo, R. T., Bromwich, D., Cattani, O., Delmotte, M., Falourd, S., Frezzotti, M., Gallée, H., Genoni, L.,Isaksson, E., Landais, A., Helsen, M. M., Hoffmann, G., Lopez, J., Morgan, V., Motoyama, H., Noone, D., Oerter, H., Petit, J. R., Royer, A., Uemura, R., Schmidt, G. A., Schlosser, E., Simoes, J. C., Steig, E. J., Stenni, B., Stievenard, M., van den Broeke, M. R., van de Wal, R. S. W., van de Berg, W. J., Vimeux, F., and White, J. W. C.: A Review of Antarctic Surface Snow Isotopic Composition: Observations, Atmospheric Circulation, and Isotopic Modeling, J. Climate, 21, 3359-3387, doi:10.1175/2007JCLI2139.1, 2008.

Meredith, M. and King, J. C.: Rapid climate change in the ocean west of the Antarctic Peninsula during the second half of the 20th century, Geophys. Res. Lett., 32, L19604, doi:10.1029/2005GL024042, 2005.

Meyer, H., Schönicke, L., Wand, U., Hubberten, H. W., and Friedrichsen, H.: Isotope Studies of Hydrogen and Oxygen in Ground Ice - Experiences with the Equilibration Technique, Isot. Enviro. Healt. S., 36, 133-149, 2000.

Noone, D.: The influence of midlatitude and tropical overturning circulation on the isotopic composition of atmospheric water vapor and Antarctic precipitation, J. Geophys. Res-Atmos., 113, D04102, doi:10.1029/2007jd008892, 2008.

Noone, D. and Simmonds, I.: Sea ice control of water isotope transport to Antarctica and implications for ice core interpretation, J. Geophys. Res., 109, D07105, doi:10.1029/2003jd004228, 2004.

Peel, D. A., Mulvaney, R., and Davison, B. M.: Stable-Isotope/AirTemperature relationship in ice cores from Dolleman Island and the Palmer Land Plateau, Antarctic Peninsula, Ann. Glaciol., 10, 130-136, 1988.

Rau, F. and Braun, M.: The regional distribution of the dry-snow zone on the Antarctic Peninsula north of 70S, Ann. Glaciol., 34, 95-100, 2002.

Rayner, N. A., Parker, D. E., Horton, E. B., Folland, C. K., Alexander, L. V., Rowell, D. P., Kent, E. C., and Kaplan, A.: Global analyses of sea surface temperature, sea ice, and night marine air temperature since the late nineteenth century, J. Geophys. ResAtmos., 108, 4407, doi:10.1029/2002jd002670, 2003.

Rignot, E., Casassa, G., Gogineni, S., Kanagaratnam, P., Krabill, W., Pritchard, H., Rivera, A., Thomas, R., Turner, J., and Vaughan, D.: Recent ice loss from the Fleming and other glaciers, Wordie Bay, West Antarctic Peninsula, Geophys. Res. Lett., 32, L07502, doi:10.1029/2004GL021947, 2005.

Rozanski, K., Araguás-Araguás, L., and Gonfiantini, R.: Isotopic Patterns in Modern Global Precipitation, in: Climate Change in Continental Isotopic Records, edited by: Swart, P. K., Lohman, K. C., McKenzie, J., and Savin, S., American Geophysical Union, Washington, USA, 1993.

Rückamp, M., Blindow, N., Suckro, S., Braun, M., and Humbert, A.: Dynamics of the ice cap on King George Island, Antarctica: field measurements and numerical simulations, Ann. Glaciol., 51, 80-90, 2010.

Shepherd, A., Wingham, D., and Rignot, E.: Warm ocean is erod- 
ing West Antarctic Ice Sheet, Geophys. Res. Lett., 31, L23402, doi:10.1029/2004GL021106, 2004.

Sime, L. C., Marshall, G. J., Mulvaney, R., and Thomas, E. R.: Interpreting temperature information from ice cores along the Antarctic Peninsula: ERA40 analysis, Geophys. Res. Lett., 36, L18801, doi:10.1029/2009g1038982, 2009.

Simões, J. C., Bremer, U. F., Aquino, F. E., and Ferron, F. E.: Morphology and variations of glacial drainage basins in the King George Island ice field, Antarctica, Ann. Glaciol., 29, 220-224, 1999.

Simões, J., Ferron, F., Bernardo, R., Aristarain, A., Stievenard, M., Pourchet, M., and Delmas, R.: Ice core study from the King George Island, South Shetlands, Antarctica, Pesquisa Antártica Brasileira, 4, 9-23, 2004.

Smith, S. R., Legler, D. M., and Verzone, K. V.: Quantifying uncertainties in NCEP reanalyses using high-quality research vessel observations, J. Climate, 14, 4062-4072, 2001.

Steig, E. J., Schneider, D. P., Rutherford, S. D., Mann, M. E., Comiso, J. C., and Shindell, D. T.: Warming of the Antarctic ice-sheet surface since the 1957 International Geophysical Year, Nature, 457, 459-462, 2009.

Stenni, B., Masson-Delmotte, V., Selmo, E., Oerter, H., Meyer, H., Röthlisberger, R., Jouzel, J., Cattani, O., Falourd, S., Fischer, H., Hoffmann, G., Iacumin, P., Johnsen, S. J., Minster, B., and Udisti, R.: The deuterium excess records of EPICA Dome C and Dronning Maud Land ice cores (East Antarctica), Quat. Sci. Rev., 29, 146-159, 2010.

Tedesco, M., Abdalati, W., and Zwally, H. J.: Persistent surface snowmelt over Antarctica (1987-2006) from $19.35 \mathrm{GHz}$ brightness temperatures, Geophys. Res. Lett., 34, L18504, doi:10.1029/2007g1031199, 2007.

Thomas, E. R. and Bracegirdle, T. J.: Improving ice core interpretation using in situ and reanalysis data, J. Geophys. Res., 114, D20116, doi:10.1029/2009jd012263, 2009.

Thomas, E. R., Marshall, G. J., and McConnell, J. R.: A doubling in snow accumulation in the western Antarctic Peninsula, Geophys. Res. Lett., 35, 1-5, L01706, doi:10.1029/2007GL032529, 2008.

Thompson, D. W. J. and Solomon, S.: Interpretation of Recent Southern Hemisphere Climate Change, Science, 296, 895-899, doi:10.1126/science.1069270, 2002.
Turner, J., Colwell, S. R., Marshall, G. J., Lachlan-Cope, T. A., Carleton, A. M., Jones, P. D., Lagun, V., Reid, P. A., and Iagovkina, S.: The SCAR READER project: Toward a high-quality database of mean Antarctic meteorological observations, J. Climate, 17, 2890-2898, 2004.

Turner, J., Colwell, S. R., Marshall, G. J., Lachlan-Cope, T. A., Carleton, A. M., Jones, P. D., Lagun, V., Reid, P. A., and Iagovkina, S.: Antarctic climate change during the last 50 years, Int. J. Climatol., 25, 279-294, 2005.

Turner, J., Bindschadler, R., Convey, P., di Prisco, G., Fahrbach, E., Gutt, J., Hodgson, D., Mayewski, P., and Summerhayes, C. (Eds.): Antarctic Climate Change and the Enviroment, 1st edn., Scientific Commitee on Antarctic Research, Cambridge, 2009.

Uemura, R., Matsui, Y., Yoshimura, K., Motoyama, H., and Yoshida, N.: Evidence of deuterium excess in water vapor as an indicator of ocean surface conditions, J. Geophys. Res., 113, D19114, doi:10.1029/2008JD010209, 2008.

van den Broeke, M., van de Berg, W. J., and van Meijgaard, E.: Snowfall in coastal West Antarctica much greater than previously assumed, Geophys. Res. Lett., 33, L02505, doi:10.1029/2005g1025239, 2006.

van Lipzig, N. P. M., King, J. C., Lachlan-Cope, T. A., and van den Broeke, M. R.: Precipitation, sublimation, and snow drift in the Antarctic Peninsula region from a regional atmospheric model, J. Geophys. Res., 109, D24106, doi:10.1029/2004jd004701, 2004.

van Ommen, T. D. and Morgan, V.: Calibrating the ice core paleothermometer using seasonality, J. Geophys. Res-Atmos., 102, 9351-9357, 1997.

Vaughan, D. G., Marshall, G. J., Connolley, W. M., Parkinson, C., Mulvaney, R., Hodgson, D. A., King, J. C., Pudsey, C. J., and Turner, J.: Recent Rapid Regional Climate Warming on the Antarctic Peninsula, Climatic Change, 60, 243-274, 2003.

Weatherly, J. W., Walsh, J. E., and Zwally, H. J.: Antarctic Sea Ice Variations and Seasonal Air-Temperature Relationships, J. Geophys. Res-Oceans, 96, 15119-15130, 1991.

Wen, J. H., Kang, J. C., Han, J. K., Xie, Z. C., Liu, L. B., and Wang, D. L.: Glaciological studies on the King George Island ice cap, South Shetland Islands, Antarctica, Ann. Glaciol., 27, 105-109, 1998.

White, W. B. and Peterson, R. G.: An Antarctic circumpolar wave in surface pressure, wind, temperature and sea-ice extent, Nature, 380, 699-702, 1996. 